San Jose State University

SJSU ScholarWorks

Master's Theses

Master's Theses and Graduate Research

1995

\title{
The role and development of libraries and the library profession in contemporary People's Republic of China
}

\section{Zhiping Li}

San Jose State University

Follow this and additional works at: https://scholarworks.sjsu.edu/etd_theses

\section{Recommended Citation}

$\mathrm{Li}$, Zhiping, "The role and development of libraries and the library profession in contemporary People's Republic of China" (1995). Master's Theses. 1158.

DOI: https://doi.org/10.31979/etd.qstj-r32h

https://scholarworks.sjsu.edu/etd_theses/1158

This Thesis is brought to you for free and open access by the Master's Theses and Graduate Research at SJSU ScholarWorks. It has been accepted for inclusion in Master's Theses by an authorized administrator of SJSU ScholarWorks. For more information, please contact scholarworks@sjsu.edu. 


\section{INFORMATION TO USERS}

This manuscript has been reproduced from the microfilm master. UMI films the text directly from the original or copy submitted. Thus, some thesis and dissertation copies are in typewriter face, while others may be from any type of computer printer.

The quality of this reproduction is dependent upon the quality of the copy submitted. Broken or indistinct print, colored or poor quality illustrations and photographs, print bleedthrough, substandard margins, and improper alignment can adversely affect reproduction.

In the unlikely event that the author did not send UMI a complete manuscript and there are missing pages, these will be noted. Also, if unauthorized copyright material had to be removed, a note will indicate the deletion.

Oversize materials (e.g., maps, drawings, charts) are reproduced by sectioning the original, beginning at the upper left-hand corner and continuing from left to right in equal sections with small overlaps. Each original is also photographed in one exposure and is included in reduced form at the back of the book.

Photographs included in the original manuscript have been reproduced xerographically in this copy. Higher quality 6" $\times 9$ " black and white photographic prints are available for any photographs or illustrations appearing in this copy for an additional charge. Contact UMI directly to order.

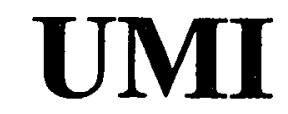

A Bell \& Howell Information Company 300 North Zeeb Road, Ann Artor MI 48106-1346 USA 

THE ROLE AND DEVELOPMENT OF

LIBRARIES AND THE LIBRARY PROFESSION IN CONTEMPORARY PEOPLE'S REPUBLIC OF CHINA

\author{
A Thesis \\ Presented to \\ The Faculty of the Department of Library and Information Science \\ San Jose State University \\ In Partial Fulfillment \\ of the Requirements for the Degree \\ Master of Library and Information Science \\ by \\ Zhiping $\mathrm{Li}$ \\ December, 1995 \\ Primary Adviser: Dr. Jo Bell Whitlatch
}


UMI Number: 1377249

\section{Copyright 1997 by \\ Li, Zhiping}

All rights reserved.

UMI Microform 1377249

Copyright 1996, by UMI Company. All rights reserved.

This microform edition is protected against unauthorized copying under Title 17, United States Code.

\section{UMI}

300 North Zeeb Road

Ann Arbor, MI 48103 
(C) 1995

Zhiping Li

ALL RIGHTS RESERVED 
APPROVED FOR THE DEPARTMENT OF DEPARTMENT OF LIBRARY AND INFORMATION SCIENCE

to Bell Whitlatch

$\frac{\text { Rueh ttafter; }}{\text { Dr. Ruth Hafter }}$

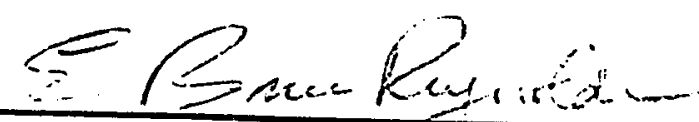

Dr. E. Bruce Reynolds

APPROVED FOR THE UNIVERSITY

yerma N. tengore 


\section{ABSTRACT \\ THE ROLE AND DEVELOPMENT OF \\ LIBRARIES AND THE LIBRARY PROFESSION IN CONTEMPORARY PEOPLE'S REPUBLIC OF CHINA}

\section{by Zhiping Li}

This thesis attempts to analyze the library system and library education in the People's Republic of China through reconstructing their historical development. Since the Chinese Communists took over the mainland in 1949, they have made all-out efforts toward the development of libraries and extension of library facilities. As a result, there has been more development of libraries after 1949 than during previous historical periods.

However, the Chinese Communists confined the new library system within a very narrow set of political goals as a tool of state machinery. While the expansion of the system was unprecedented, its suppression of political or intellectual freedom was also unprecedented. The same can be said for library education.

The Chinese political and economic reforms initiated in late 1978 have changed the roles of library and information services enormously. Libraries and information centers are playing an important part in the modernization drive. The application of modern technology in the libraries has created a great demand for well-trained and qualified librarians and information specialists. Library education programs have greatly expanded in the last decade. Nonetheless, with all this transformation, what remains basically intact is the subordination of the library system and library education to the political interests of the government. 


\section{ACKNOWLEDGMENTS}

I would like to express my gratitude to Dr. Jo. Bell Whitlatch, who, as my adviser, critic and editor, has read and commented upon the entire manuscript. Her profound knowledge of Asian and Chinese cultures has been an indispensable source of academic perspective. She has favored me with her enthusiastic guidance, valuable editing and great support from the very inception of my thesis. My sincere thanks also go to Dr. Ruth Hafter and Dr. Bruce Reynolds for their cordial assistance in the completion and evaluation of my thesis. 


\section{TABLE OF CONTENTS}

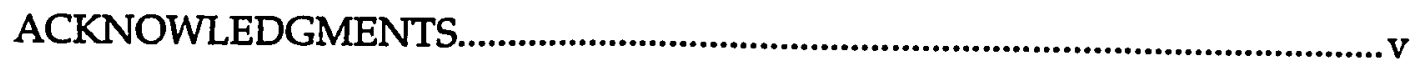

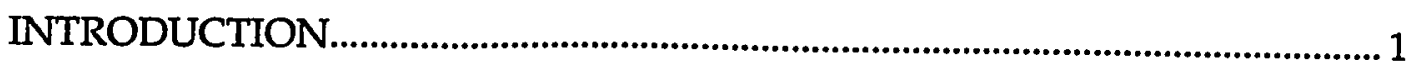

Chapter

I. LAND, PEOPLE, AND BACKGROUND........................................... 7

II. THE DEVELOPMENT OF THE LIBRARY SYSTEM IN COMMUNIST CHINA.................................................................29

III. LIBRARY EDUCATION IN COMMUNIST CHINA....................... 77

IV. SUMMARY AND CONCLUSIONS..................................................104

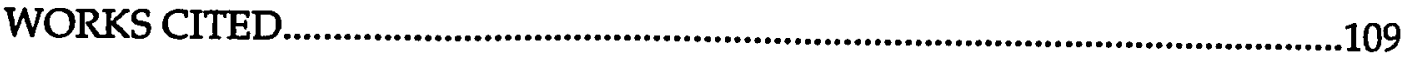




\section{INTRODUCTION}

At the end of the 1970s, in initiating the "Open Door Policy," Deng Xiaoping ${ }^{1}$ declared: "No country can now develop by closing its door.... We suffered from this and our forefathers suffered from this. Isolation landed China in poverty, backwardness and ignorance." 2 Since then, China's reform has lasted 14 years, surging from the countryside to the city, from the economic system to the social and political systems and from revitalizing the domestic economy to opening to the outside world. Through the reform and opening to the outside world, a more positive approach and active attitude towards Western civilization has been adopted. All these events have changed the roles and functions of library and information services enormously. Libraries and information centers are becoming an important part of society in improving the intellectual level of the whole nation, serving the economic and political reform programs, and meeting the needs of the modernization drive. As a popular Chinese slogan says, "it is a period full of challenges and opportunities." The application of modern technology in library and information service has also challenged professional education for library and information personnel in China.

What has taken place in China in the past several years is vastly different from its time-honored past. The rulers of China always imposed severe surveillance upon the people. One of the essential policies in this respect has been a strict control of knowledge, and the authorities often achieved this by restricting the access to books and libraries. The most notorious case occurred in 221 BC, when the Emperor Qin Shihuang 
(221-207 BC) burned the unapproved books which were produced during the Warring States period. He also ordered all historical records which were not written by Qin historians be burned. Complete libraries which contained valuable books were thus destroyed. 3 In revolutionary China Mao praised the Qin emperor's book burning, and during the Cultural Revolution, this historical tragedy was replayed only with far greater magnitude. Across the nation, libraries were closed down, and tens of millions of books were thrown into flames.

When the Chinese Communists gained control over Mainland China in 1949, China underwent many political, social, and economic changes. These changes have also been reflected in library development. This is especially true in the cases of the Great Leap Forward (1958-59) 4 and the Cultural Revolution (1966-76). 5 In the history of the People's Republic (1949to the present), all-out efforts have been made toward the development of libraries and extension of library facilities. However, under Mao's closeddoor policy and centralized economic planning there was less demand for information, librarians and information specialists. Therefore, the progress of library education in China moved very slowly until the 1980 s. 6 Libraries are always affected by the current economic situation. During the past 50 years, library development has followed a tortuous road. Even though it has been up and down, generally speaking, more development of libraries took place after 1949 than during previous periods. All types of libraries increased greatly. 7

Due to the nature of its highly-centralized and authoritarian political system, China effects an all-encompassing censorship on publications. It is 
systematic "decontamination,"8 a daunting task indeed since under the political microscope there is nothing trivial and negligible. Surges of political movements come and go, but the regime has never relaxed its alert on the "negative" power of knowledge. Books with undesirable content have been sorted out, burnt, or stored away eternally like nuclear waste. What has been treated as poisonous waste includes printed matter related to the subject fields of capitalism, imperialism feudalism, idealism, fatalism, pornography, superstition, chivalrous fiction, rightist writings, counterrevolutionary ideas, and so on. 9

Under Deng Xiaoping's modernization reform, libraries and information centers are becoming an important part of society in improving the intellectual level of the whole nation, and serving the economic and political reforms. Demands for well-trained and qualified librarians and information specialists are immense, which, in turn, also stimulate the development of library education. This thesis will describe how Chinese libraries have coped with all the political ups and downs in China, how Chinese Communism has controlled the growth and development of the library systems, how the different library systems have been influenced by Chinese Communist political dynamics, and what China has done to train the necessary personnel to staff the libraries after the founding of the People's Republic of China (PRC) in 1949. It is, in fact, a brief account of the history of Chinese libraries under Communism based on available Chinese and English materials. 
To analyze the development of the library in China, I hypothesize that, for the Communist ruling elite, the library is a viable and effective instrument for guiding and controlling the masses toward the construction of a Communist society. Library service is geared to the Communist Party's cultural policy "to serve the politics of the proletariat, to serve production, and to serve the workers, peasants and soldiers."

Libraries under the Communist system have been organized into a system to serve the People's Republic of China. Thus, my thesis will shed light on the twofold role of the library system in China: (1) making the most effective system to serve the Communists for political indoctrination at the outset and maintenance of the socialist state on a continuing basis; and (2) placing great emphasis on the need for scientific library materials to support the economic and technical needs of the Chinese Communists to increase production. These two factors directly influenced and affected library personnel staff training, library organization and operations and library development, as well as library network communication on both a national and international level. There will be a thorough consideration of the relationship of these two primary functions of libraries to the growth and development of libraries in the People's Republic of China.

Chapter 1, "Land, People, and Background," presents a brief and necessary account of modern China, its historical background, social system, geographic and demographic features, and its current social, economic, and political status.

Chapter 2, "Library Development in Communist China," starts with a brief historical review of the old library system from imperial times to the 
early modern era before 1949. The system of libraries in China after the Communist takeover is analyzed through a chronological approach. Policies, structural adjustment, and significant expansion of libraries are oriented according to the shift or persistence of the political and ideological center of gravity.

Chapter 3, "Library Education in China after 1949," delineates the emergence of modern library education and the important impacts that the political situation and development have exercised upon librarianship in new China.

Chapter 4, "Summary and Conclusions," contains the major conclusions with particular reference to the role of libraries and library education in the different historical periods. 
NOTES

1Deng Xiaoping, 1904-, Chinese Communist leader, has been twice purged from power $(1976,1977)$, and twice rehabilitated $(1973,1977)$. He became powerful as Communist party deputy chairman (1977), and at the 1982 Communist Party Congress. He was named to lead the newly created Central Advisory Commission. 1993): 55-57.

2Jianxin Wu, "Moving into the Big time," Beijing Review no. 2 (May 13.

${ }^{3}$ Steven Dahl, History of the Book (New York: Scarecrow Press, 1958),

4 The Great Leap Forward (1958-1960) was a program which sought to make use of China's rural manpower surplus to rapidly expand agricultural and small-scale industrial productivity but led instead to general economic dislocation.

5 The Cultural Revolution (1966-76) was designed to shake up an increasingly self-conscious and conservative party-government-militarypower elite and to replace it with more revolutionary elements.

6Weiming Li, "Professional Education for Library and Information Personnel in China," International Library Review 21(2) (April 1989): 263-275.

7Julia Wang, A Study of the Criteria for Book Selection in Communist China's Public Libraries. (Hong Kong: Union Research Institute, 1968), 144.

${ }^{8}$. Stones, "An Introduction to Children's Books in the People's Republic of China," Bookbire 15 (1) (1977): 8-18.

9Lee-hsia Hsu Ting, "Chinese Libraries and Library Education, 19491980: Truth and Myth in the People's Republic of China," paper presented at the 100th annual conference of the American Library Association, 29 June 1981, 1-28, EDRS, ED 214516, microfiche. 


\section{Chapter I \\ LAND, PEOPLE, AND BACKGROUND}

The pressing need for changes in the current patterns of Chinese libraries and library education will not be fully understood, unless we put it in the contextual perspective of historical, social, economic and political dimensions. In the following pages, I will address these issues in detail.

The land and the people. China (officially the People's Republic of China), was established in 1949, but the name China, which is commonly used by foreigners, is probably derived from the Qin dynasty (221-206 BC), which first unified the nation. The Chinese themselves use the name Zhonghua (Middle Country) which originated with early Chinese concept that China was in the center of the world. 1

The topography of China is often described roughly as forming three levels of elevation. The three elevation levels cross China in roughly northsouth vertical bands and are themselves crossed by prominent east-west horizontal mountain ranges that subdivide the three elevation regions into nine subregions. 2

China's vast area of $3,691,500$ square miles $(9,560,940 \mathrm{sq}$. $\mathrm{km})$ excluding Taiwan is slightly larger than that of the United States. Its coastline, bordering on the Yellow, East China, and South China seas, is about 12,000 $\mathrm{km}$ long. China shares a land border of about 21,260 km with 11 other countries: North Korea, the former USSR, Mongolia, Afghanistan, India, Pakistan, Nepal, Bhutan, Burma, Laos, and Vietnam. Other neighbors 
include the British Crown Colony of Hong Kong (which will be turned over to the PRC in 1997) and the Portuguese territory of Macao. The offshore island of Taiwan is a separate political entity from China, which has continued since 1949 to demand the return of the island to its political jurisdiction. 3

China, a nation of Asia, has more than a fifth of world's population, and is the world's third largest country in area. According to China's third national census, in 1993, the country's total population was $1,178,500,000$ excluding 18,270,749 people who lived on the island of Taiwan. The census confirmed what had already been known, that China was by far the most populous nation in the world. For many years, Chinese government population growth policies fluctuated. In 1979 China launched a campaign for the one-child family. 4

Ethnically, more than 90 percent of China's population are Han Chinese. Because of migration, their proportion in the areas occupied by minorities is increasing, but for the most part they continue to live in the eastern two thirds of China. The minorities, such as the Zhuang, the Hui, the Uygurs, the Yi, the Miao, and the Tibetans, live in the vast, sparsely settled territories of northwest, west, and southwest China. According to the 1982 census, the national minorities had increased to 67.2 million and, because of higher fertility, their proportion had increased to 6.7 percent of the population.

Chinese, spoken by the Han nationality, is a Sino-Tibetan language. All Chinese use the same written language, but the diversity of the spoken 
dialects is so great that people from different regions often cannot understand each other. About 70 percent of the Han population speaks Mandarin. In its efforts to unify the Chinese population, the government has tried to cope with some of the divisive characteristics of the Chinese language. It has attempted to make Mandarin the standard vernacular and has encouraged the study of Mandarin by non-Han ethnic groups. Mandarin is taught in almost all Chinese schools and used in the national broadcast media. 5

Historical background. China has been a communist country for only a little more than forty-five years. For most of the centuries between the Shang dynasty in about 1550 BC and the collapse of the Qing Dynasty in 1911 China was ruled by a series of emperors.

From its origins in the middle reaches of the Yellow River, Chinese civilization quickly expanded south to the valleys of the Yangtze River and its tributaries, and northwards into present-day Liaoning. The first documented Chinese civilization was the Shang Dynasty (c. 1523-c.1027 BC), which had cities, bronze metallurgy, and a system of writing. It was supplanted by the Zhou (c. 1027 BC - 256 BC), which gave rise to China's golden age of philosophy, highlighted by the works of Confucius, Laotze, and Mencius. The capital of Zhou remained the ritual center of a patchwork of feudal states for almost a millennium, but real power was divided among rival states. One of these states, the Qin, finally crushed its last opponent and unified China in $221 \mathrm{BC} .6$

The Qin Dynasty (221-207 BC) united China under a centralized imperial system; construction of the Great Wall was begun during this period. 
The Qin collapsed 11 years later and was succeeded by the Han, which extended its influence over most of what is present-day China, including the overland silk routes to the West as far as present-day Kirgyzstan. The Han was notable for its long, peaceable rule, territorial expansion, and technological and artistic achievement. Despite interruptions and episodes of instability, the Han Dynasty endured for 400 years until AD 220.7

After more than three centuries of disunion, China was reunited under the Sui (581-618) and the Tang (618-907). The military might of the Tang and its culture radiated throughout Asia, transforming the indigenous societies of present-day Japan, Korea and Vietnam. Threatened by the Turkish tribes in the north and the Tibetan empire to the west, the Tang organized powerful military commands on its frontiers whose growing autonomy and power eventually eclipsed that of the dynastic capital at Chang'an, present-day Xian.

The Song Dynasty (960-1126) marked a period of rapid economic and commercial development. Total population reached 100 million. This was a time of scholarly studies and artistic progress, marked by the invention of moveable type. Mongol armies led by Genghis Khan began their invasion of China in the early 13th Century and completed their conquest 50 years later. 8

The Mongols, who built the Yuan empire (1260-1368) with the capital at Peking, were expelled in 1368 by Zhu Yuanzhang, the founder of China's last native dynasty, the Ming (1368-1644), whose power dominated Asia for nearly three centuries. A six-year war with Japan in the 1590s, over control of Korea, 
bankrupted the court and began a process of military decline culminating in the Manchu conquest of China in $1644 .{ }^{9}$

China's defeat by Britain in the Opium War in 1841-42 began a process of virtual dismemberment by Western imperialist powers. China nominally became a republic after the collapse of the weakened Manchu Qing Dynasty in 1911, but real power was dispersed among regional warlords until 1927, when the Guomindang under Chiang Kai-shek undertook the Northern Expedition and established a new government at Nanjing. Chiang unleashed a campaign of extermination against his erstwhile allies, the Chinese Communist Party (CCP), who in 1936 were driven from their rural base areas in Southern China into northern Shaanxi.10

Japan's invasion of Manchuria in 1931 and the opening of full-scale hostilities in 1937 gave the CCP a second lease on life. Chiang was forced to suspend his campaign against the Communists, who built up a network of powerful guerrilla resistance organizations behind Japanese lines in northern and eastern China. Civil war between the CCP and Guomindang resumed after Japan's surrender to Allied Forces in 1945. Four years later Mao Zedong proclaimed the People's Republic of China in Tiananmen Square in Beijing.

Chiang and his Guomindang forces retreated to the island of Taiwan, and claimed (as the Republic of China) to be the legal government of the entire country. But the history of post-1949 China is the history of the People's Republic, proclaimed by Mao Zedong on Oct. 1, 1949 at its capital Beijing. 
With the proclamation of the People's Republic in Oct.1949, the Chinese Communist Party established a new form of state power. Called "people's democratic dictatorship," it was modeled after the Soviet dictatorship of the proletariat, but with an important difference: in theory, people's democratic dictatorship embodied the united front tactics of Mao's new democracy. At the center of power was the CCP, a well-disciplined and hierarchically organized elite including roughly two to four percent of China's total population. Within this elite, and particularly within its central committee of a few hundred top leaders, all major decisions affecting China's social, economic, military, and foreign policies were made. From 1949, when Mao Zedong proclaimed the birth of the People's Republic of China, until his death in 1976, he dominated Chinese politics. Mao was a man of great revolutionary vision and strategic genius.

The crisis of Chinese communism in the 1990s does not obscure its early achievements. Even the propagandists could claim correctly in the 1950s that the government's first Five-Year Plan (1953-1957) was a major success. Modeled on the state-controlled industrial production strategies used in the Soviet Union at the time, the Plan succeeded in part because it started from such a low economic base. Nevertheless, it was a daring and radical reorganization of the Chinese economy. 11

One of the most fundamental changes was a 1950 Land Reform Law that deposed landlords and redistributed their property to the peasants. The primary agents of this change were Communist Party members called cadres who moved to the countryside and established the village Peasant 
Associations that were to become the instruments of Party control. Similarly, by 1952 most of the industrial holdings in private hands had been consolidated under government control; the owners of factories were systematically tried and persecuted. This transition was a brutal and traumatic affair for the private owners whose lives and families were thereafter shattered. For their part, the Communists found that the process of breaking up the economic base of the bourgeoisie greatly strengthened their confidence and that of the people in the Party's leadership. By the end of 1952 the Party had allotted membership to 6 million people. ${ }^{12}$

China intervened in the Korean War (1950-53) in October 1950 as United Nations (UN) troops reached the Sino-Korean border. By mid-1951, China had pushed the UN forces back to a line near the thirty-eighth Parallel. The conflict led Washington to deploy the U.S. 7th Fleet in the Taiwan Straits in defense of Taiwan, effectively committing both the U.S. and China into postures of mutual hostility that would persist for two decades. China also invaded Tibet during this period.

Back at home, despite the skepticism of the Liu Shaoqi-Deng Xiaoping group, Mao moved to relax political control to allow a degree of open public debate. The "Hundred Flowers Movement" (1957-58) quickly got out of hand, however, as university students, journalists and some officials directly attacked the Party and its monopoly of political power. Stung, the Party moved quickly to reimpose limits on debate and conducted a purge of liberal intellectuals. Nearly half a million people were stigmatized during the 
"Anti-Rightist Campaign,"(1957-58); many were banished to labor camps in remote areas of China.

Mao eagerly welcomed Soviet economic and technical assistance in the design and implementation of China's first five-year plan for economic development in 1953 only to reject Soviet advice a few years later, when he launched his "Great Leap Forward." Abandoning the Eighth Congress program of sober, planning-based, Soviet-style economic development, Mao decided that China could rapidly develop both industry and agriculture through more extensive rural collectivization and decentralized economic decision-making. By the end of 1958, almost all of the rural populace had been incorporated into some 25,000 people's communes. The communes were intended to swiftly increase agricultural output by imposing militarylike organization and labor-intensive projects such as dams and irrigation systems. Industrial output targets were revised upwards sharply, and localities established many small "backyard" factories to produce steel and other goods. In December, partly in response to the failure of the policy of the Great Leap Forward, ${ }^{13}$ (1958-59) Mao withdrew from active participation in day to day decision-making. 14

Increasingly marginalized, Mao launched the Cultural Revolution in 1966, which convulsed China for nearly a decade. Mao's attack on the orthodox Party bureaucrats who had supplanted his leadership initially focused on purification of cultural and educational policy, but the target of the campaign quickly broadened to encompass "power-holders in the Party who take the capitalist road." A Mao-endorsed critique of the play, "Hai Rui's 
Dismissal," fueled a rectification campaign which lead to the Cultural Revolution ${ }^{15}$ (1966-76).

A last-minute attempt by Liu and Deng to ease Mao out of the leadership by convening a special Central Committee Plenum in June 1966 was blocked by military forces under defense minister Lin Biao. With Lin's support, leftists convened their own plenum in August, excluding more than half of the regular central committee membership, affirming Mao's Cultural Revolution policies and naming Lin Vice-Chairman.

The leftists also mobilized college and secondary school students to attack teachers and local Party leaders. These Red Guard groups were responsible for persecuting and torturing hundreds of thousands of people and the destruction of books, temples, museums, and cultural artifacts. Violent clashes between rival Red Guard groups, some secretly backed by Party leaders under attack by Maoists, occurred all over China.

In early 1967, after Liu, Deng and most of their supporters in the central leadership had been humiliated and purged, the Maoists focused their attention on local Party organizations. In the provinces and countryside, however, there was mass resistance to the Red Guards, including workers organized by local Party leaders, leading to military intervention.

Mao's January directive to Lin calling on the military to intervene in support of the Left brought into the open the divisions within the People's Liberation Army (PLA) between the central military organization controlled by $L$ in and the regional commanders. Some local military leaders supported 
the Maoists, others resisted them, while others attempted to remain neutral. By mid-1967, serious armed clashes had occurred among military units and Red Guard groups all over China.

The threat of civil war led to a realignment among the surviving power centers in 1967 as Lin, regional military commanders and premier Zhou Enlai began to cooperate to contain the Left. Mao acquiesced as joint PLA-worker units suppressed Red Guard organizations, many of whom were sent to the countryside in 1968-70. By 1969, a new Party leadership had coalesced in the form of a coalition between Maoist leftists, the military under Lin, and the surviving elements of the state bureaucracy under Zhou, which began the reconstruction of Party and civil government organization.

Hua Guofeng became premier in February 1976 following Zhou's death, and radical elements in the leadership mounted a new attack on Deng, apparently supported by Mao who was by then seriously ill. The removal of wreaths memorializing Zhou from Tiananimen Square sparked a massive anti-radical demonstration in April. Deng was blamed for the riot and removed again from posts as Vice-Premier and member of the politburo Standing Committee, retaining only his Party membership. 16

Shortly after Mao's death in September 1976, Hua arranged for the arrest of Mao's widow, Jiang Qing and other key leftist leaders, later known as the Gang of Four, with the support of senior military leaders. Hua was named Party Chairman in October. Deng was restored to his posts in 1977. 
The successful reversal of the radical verdict on the Tiananmen Movement which caused the downfall of Deng17 encouraged new and more radical demands for polisical liberalization and democracy. Activists presented critical ideas in wall posters at Xidan Wall in Beijing and in other cities as well as establishing new unofficial magazines. Under pressure from other Party leaders, Deng set forth new limits to political reform at a politburo meeting in March 1979 in the form of the Four Basic Principles ("Upholding the socialist road, dictatorship of the proletariat, leadership of the Communist Party and Marxism-Leninism-Mao Zedong Thought"). Democracy Wall18 was closed and a number of democratic activists (the most prominent of whom was Wei Jingshen) were arrested and tried. Many remain in detention.

Drastic reform took place in the economic structure of China in the post-Mao era. Deng and his allies progressively abandoned collectivized land ownership and legitimized free market forces in the economy while opening the country to Western investment and cultural influences. But the CCP continues to cling tenaciously to its monopoly on political power. The most significant challenge to $\mathrm{CCP}$ dominance came when student protests after the death of former Party General Secretary Hu Yaobang in April 1989 quickly expanded into huge mass demonstrations in Beijing's Tiananmen Square. Party and government officials openly participated in protests for democratic reforms, action against official corruption, and called on Li Peng to resign and Deng to step down. More demonstrations erupted in other cities throughout China. 
The Party leadership was split between liberals headed by Zhao Ziyang, who urged that concessions be made to the protesters, and hardliners, headed by $\mathrm{Li}$ and state president Yang Shangkun, backed by Deng. The impasse was broken by the intercession of veteran retired and semi-retired Party leaders including Chen Yun, Li Xiannian, Peng Zhen and Wang Zhen. Li declared martial law in Beijing on May 20, but demonstrators used trucks and buses to block key intersections on successive nights to keep People's Liberation Army (PLA) units from entering the city in force.

Troops supported by armored vehicles finally forced their way into Beijing on the night of June 3, overcoming violent resistance by demonstrators who threw rocks and Molotov cocktails, destroying hundreds of tanks, armored personnel vehicles, trucks and buses. Hundreds of demonstrators and onlookers and dozens of soldiers, were killed. Rui Xingwen and Yan Mingfu were removed from the Party Secretariat. Jiang Zemin replaced Zhao as Party General Secretary. Jiang, Li Ruihuan and Song Ping were named to the politburo standing committee. 19

Present government. China is a Communist state, with all authority resting in the CCP. The country has had five constitutions since the Communists reorganized the national government 1949. The National People's Congress (NPC) is the highest organ of state power. It can amend the constitution, elect to or remove from office the highest state dignitaries, and decide on the national economic plan. The NPC elects a Standing Committee, whose chairman is equivalent to the head of state. The NPC is composed of deputies elected to 5-year-terms. 
For local administrative purposes China is divided into 21 provinces (not including Taiwan), 5 autonomous regions, where other ethnic groups, such as the Zhuang, the Hui, the Uygurs, the $Y_{i}$, the Miao, and the Tibetan, constitute a majority of the population, and 3 cities (Beijing, Tianjin, and Shanghai) directly under central government control. The provinces and autonomous regions are broken down into prefectures, cities, counties and special districts. The counties are further broken down into rural and urban administrative units, communes, and towns, respectively. Provinces and autonomous regions are governed by Local People's Congresses, and lower levels of government, by local People's Governments. 20

Foreign Policy. China's foreign policy has changed significantly in several ways since Mao Zedong's death in 1976 and the subsequent ascendancy of the reformists headed by Deng Xiaoping since late 1978. The revolutionary rhetoric and support for insurgency movements in Southeast Asia that characterized China's regional involvement during the Maoist era has been transformed into a more stable and pragmatic foreign policy rationally linked with security and economic interests.

The decision-making process in Chinese foreign policy has become somewhat less personalized and idiosyncratic. In his day, Mao dominated the process and defined China's international role, while Zhou Enlai acted as principal advisor and implemented foreign policy. In contrast, Deng Xiaoping turned toward a more collegial style while remaining the guiding strategist on major policy questions. 
The policy directions established by Deng also differ from those set by Mao in substance and their longer term implications. The Maoist policy of economic self-reliance and isolationism was discredited and overturned. The open-door policies of the reformers resulted in a growing network of vested interests in trade, technology, and capital relations with the outside world. As China's economy has become increasingly integrated with the world economy, the policies that have facilitated this cannot be reversed without serious economic hardship and political cost.

These changes have brought China into the international community as a nation acting among nations, pursuing goals and choosing means common to most states. There are, however, at least two ways in which China's foreign policy remains qualitatively different from those of most other Asia-Pacific countries. First, Chinese leaders believe that China, by virtue of its history, size, population, and economic potential, is or should be a global power. Although Chinese foreign policy is no longer couched in terms of revolutionary rhetoric, it is often cast in terms of global principles, issues, and objectives. China's smaller neighbors also have difficulty in perceiving China as just another nation-state. Second, China is a divided nation, and the reunification of Taiwan with the mainland continues to be a programmatic goal that affects foreign policy. 21

Economy. Since 1949, China has had a centrally planned economy, nationalized all heavy industry and pursued a policy of rapid, decentralized, state-directed industrialization, with special emphasis on the development of heavy industry. China has undergone great and rapid changes in its 
economy. China has generally moved from an overcentralized planned economy to a market economy, swinging back and forth. At present, the proportion of products under state planning has decreased in total industrial value and the means of production under unified state distribution have been reduced in number. Since the reform and opening to the outside world, the Chinese people of various nationalities have written a new chapter in the history of the country's development with the increased rate of growth in the gross national product (GNP). 22

Despite the rapid industrialization of recent years, China remains a predominantly agricultural country, with an estimated 76 percent of the labor force engaged in agricultural activities in 1984. Food grains constitute the principal crop grown in China, the leading food grains being rice, wheat, corn, millet, and kaoliang (a form of sorghum). Rice is the leading food grain.23

China's reform first took place in the countryside, because agriculture is the foundation of the national economy and more than 800 million people live in the countryside. Agriculture is vitally important to the nation's development and improvement of people's living standards. In the early 1980s the people's communes-organizations (founded in 1958) that integrated government administration and economic management were dismantled and the household contract responsibility system, with remuneration linked to output, was introduced. The peasants have gained the power to make their own decisions about production. 24

People in rural and urban areas have enjoyed tangible benefits from the reform and opening to outside world. The problem of food and clothing 
has basically been solved, people's living standards have been improved greatly, and the market supply of nonstaple food is ample.

Education and Politics. The pattern of educational development in the People's Republic of China has reflected the larger picture of national politics. It has been equally turbulent, with its own ups and downs, advances and retreats. The task of creating a new national system of education on the basis of a new ideology has undergone several major policy shifts.

From 1949 to 1952, after 12 years of war, all-out efforts were made to restore educational order, to reorganize schools on all levels, and to prepare the ground for fast expansion of educational facilities. Also during this initial phase all schools with foreign connections were taken over by the state and the "old intellectuals" were subjected to intensive thought remodeling.

The second phase, from 1953 to 1957, was a period of consolidation and expansion during which substantial gains were achieved on all fronts, from literacy classes in rural areas to post-graduate programs in major universities. Internationally China was "leaning to one side," that of the Soviet Union, and Soviet teachers and advisers came by the thousands, bringing their own pedagogy. Soviet teaching materials were adopted by the Chinese and translated in large quantities.

During the third phase, from 1958 to 1961 , China no longer followed the Soviet lead and was forced to adopt the excessively ambitious program known as the Great Leap Forward, which emphasized self-reliance. 
Education was subjected to more stringent control by party cadres and to greater demands for manual labor on the part of both teachers and students.

The fourth phase, which began in 1961 and ended with the outbreak of the Cultural Revolution in 1966, was a period of retrenchment. The moderate faction within the Communist party strove to restore a sense of normality to the schools by encouraging teachers to resume full-time professional work and by reducing the amount of labor required of students.

To Mao and his ultraleft followers, the retrenchment policy had brought about the erosion of correct political leadership and the concomitant usurpation of power by "capitalist roaders," with an inevitable relaxation of ideological rigor. 25 In their view, this policy would lead first to revisionism and ultimately to the restoration of capitalism. Therefore, it was no accident that the Cultural Revolution started on some university campuses and soon spread to all parts of the country. For a decade or more after 1966, educational activity was subordinated to "proletarian politics" and "productive labor," resulting in what has been described as the "loss of a whole generation of intellectuals."

The death of Mao and the subsequent down-fall of the radical leftist Gang of Four brought this catastrophic national movement to an end. With the rise of Deng Xiaoping to power in 1978, a "New Era" of pragmatism began in earnest, with the design of achieving China's modernization by the year 2000.26 An entirely new picture of education emerged, culminating in the formation of a State Education Commission to replace the Ministry of Education in 1985. One significant source of change in the national 
educational system is the central government's 1985 "Educational Reform Decision." According to the plan, by the end of the decade there was to be a rapid diversification of secondary schooling, as the once virtually uniform academic secondary system was to be transformed into a highly differentiated, multitrack system in which more than one-half of all students were to receive vocational or technical training. Higher education systems were to extend their decision-making power in enrollment planning and subsequent job assignment of their graduates. Teachers and school administrators were to assume greater responsibilities for the reform and restructuring effort with Party organizations playing a subordinate school management role. The expansion of education was considered essential to the "massive socialist modernization program."

A second major source of change is the 1986 Law of Compulsory Education. Under the first such law since the founding of the People's Republic of China, local areas are now obligated to provide nine years of education to children. This goal of universal schooling through junior high school puts a strain on a system in which previously many children did not complete primary school. It should be noted that in 1980, only 93 percent of school-age children entered primary school, and even by 1985, the year prior to the law's enactment, only 68.4 percent of elementary school students graduated. Thus, one important change in the organizational climate of education concerns political and resource demands placed on the schools and their staffs. 27

At the national level political and economic pressures have combined to heighten the importance of local resources for schools, to increase the 
demands on the secondary system with the extension of compulsory schooling, and to alter the responsibility and authority structures in the governance of schools. These developments and the ways in which they are interpreted at the local level have the potential to make significant changes in both the governance and educational practices found in Chinese secondary schools.

In the dynamic decade of the 1980s, modernization produced dramatic changes as well as social problems. In the wake of the 1989 military crackdown and political repression, criticism of these social forms and institutional coping strategies--of charging high tuition or of transforming much-needed school space into lucrative enterprises--has grown. 28 The political climate of the early 1990s formally reasserts the authority of the Party, including its role in running schools. ${ }^{29}$ Yet the economic and demographic pressures that prompted changes in authority relations have not subsided. What form the Chinese educational system will eventually take remains an unsolved and unsettled open question. 


\section{NOTES}

1Zhi Wu, "China: History , Politics/Foreign Affairs," Far Eastern Economic Review v.57:10 (March 1991):16-17.

2Lauren S. Bahr and Bernard Johnston, eds. Collier's Encyclopedia: with Bibliography and Index (New York: P.F. Collier, 1993), s.v. "The Land," by Albert Feuerwerker.

3 Academic American Encyclopedia, 1993 ed., s.v. "Geography."

${ }^{4}$ Alexander Hopkins McDannald and others, eds. The Americana Annual: an Encyclopedia of the Events (New York: Americana Corporation, 1994), s.v. "Population," by John Bryan Starr. Groups."

5 Encyclopedia Americana, 1992 ed., s.v. "Ethnic and Linguistic

6Encyclopedia Americana, 1992 ed., s.v. "Civilization."

7Edwin G. Pulleyblank, "Records of the Grand Historian: Qin Dynasty," Pacific Affairs v.66:4 (Winter 1993): 625B.

${ }^{8}$ Zhi Wu, "China: History , Politics/Foreign Affairs," Far Eastern Economic Review v.57:10 (March 1991):16-17.

${ }^{9}$ Yule Chao, Zhongguo Chaodai Yanjiu (Studies of the Chinese dynasties) (Beijing: Commence Publishing House, 1978), 27, 64.

10Zhi Wu, "China: History , Politics/Foreign Affairs," Far Eastern Economic Review v.57:10 (March 1991):16-17.

${ }^{11}$ Chu-yuan Cheng, The Economy of Communist China, 1949-1969 (Ann Arbor: University of Michigan, Center for Chinese Studies, 1971), 24, 36.

12Encyclopedia Americana, 1992 ed., s.v. "Communism."

${ }^{13}$ The Great Leap Forward (1958-1960) was a program which sought to make use of China's rural manpower surplus to rapidly expand agricultural and small-scale industrial productivity but led instead to general economic dislocation. 
14 Mark Borthwick, Pacific Century: The Emergence of Modern Pacific Asia (Boulder: Westview Press, 1992), 404.

15The Cultural Revolution (1966-76) was designed to shake up an increasingly self-conscious and conservative party-government-militarypower elite and to replace it with more revolutionary elements.

16Zhi Wu, "China: History , Politics/Foreign Affairs," Far Eastern Economic Review v.57:10 (March 1991):16-17.

17Deng Xiaoping, 1904-, Chinese Communist leader, has been twice purged from power $(1976,1977)$, and twice rehabilitated $(1973,1977)$. He became powerful as Communist party deputy chairman (1977), and at the 1982 Communist Party Congress. He was named to lead the newly created Central Advisory Commission.

18Mark Borthwick, Pacific Century: The Emergence of Modern Pacific Asia (Boulder: Westview Press, 1992), 409.

${ }^{19} \mathrm{Zhi}$ Wu, "China: History , Politics/Foreign Affairs," Far Eastern Economic Review v.57:10 (March 1991):16-17.

20Lauren S. Bahr and Bernard Johnston, eds. Collier's Encyclopedia: with Bibliography and Index (New York: P.F. Collier, 1993), s.v. "National Government," by Thomas R. Tregear and Shane Mage.

21 Mark Borthwick, Pacific Century: The Emergence of Modern Pacific Asia (Boulder: Westview Press, 1992), 30.

22 Academic American Encyclopedia, 1993 ed., s.v. "Economy."

23 Academic American Encyclopedia, 1993 ed., s.v. "Agriculture."

24Mark Borthwick, Pacific Century: The Emergence of Modern Pacific Asia (Boulder: Westview Press, 1992), 114, 149.

25Stewart E. Fraser, Education and Communism in China (London: Pall Mall Press, 1971), 47, 61, 99.

26Maurice J. Meisner, Mao Zedong de Zhongyuo (Mao's China and After) (Beijing: Shehui Kexue Wenxue Chubansinu, 1992), 25, 33.69. 
27Brian Delany and Lynn W. Paine, "Shifting Patterns of Authority in Chinese Schools," Comparative Education Review 35 (1) (February 1991): 2343.

28 Andrew Walder, "Social Change in Post-Revolution China," Annual Review of Sociology 15 (1989): 405-25.

${ }^{29}$ Zhenghong Fu, "Jianchi Shehui Zhuyi Banxue Fangxiang de Jidian Wenti" (Several Issues Concerning the Orientation of Running Socialist Schools), \iaoyu Yanjiu (Educational Research) 1 (January 1990): 13-16. 


\section{Chapter II}

\section{THE DEVELOPMENT OF THE LIBRARY SYSTEM IN COMMUNIST CHINA}

The history of libraries in China is almost as old as the history of China itself. In the development of the library system in China, three distinct periods can be cited as having some general characteristics that have had an influence on the development of libraries. Although there was much variance in the development and attitudes toward libraries in these periods, there are certain recurrent political, social and cultural factors common to each particular period. To throw light on these factors, a very brief review of the origin and early growth of the China's library system is in order at the very outset.

First, the imperial library existed as early as the sixth century B.C. Each successive dynasty had an imperial library which served as a depository of national literature and archives; libraries during this period functioned as depositories of valuable historical records rather than as centers that were freely accessible to all. They were reserved for use by the imperial family, high officials and scholars. China therefore had an uninterrupted series of national bibliographies from the Han to the Qin dynasties (221 B.C.-1911 A.D.). Not surprisingly, China, with a civilization that encompasses five thousand years and exhibits a high degree of cultural continuity, has produced innumerable records. 1 These documents and library collections were often burned or dispersed, reflecting the political upheavals. They were almost always rebuilt in the more peaceful intervals. For example, from 
ancient times many wooden blocks were used as books. Today almost no wooden manuscripts are in existence. Emperor Qin Shihuang in 213 B.C. issued an order to destroy all books. ${ }^{2}$ This was done because of his anger towards those who were critical of his political actions.

Modern librarianship in Western terms is a fairly recent phenomenon in China. Recalling China's vulnerability following the Treaty of Shimonoseki, which followed defeat in the Sino-Japanese War (1894-1895), Li Duanfen petitioned the imperial government in 1896 to develop schools in China and to establish libraries in Beijing and the provincial capitals. In 1898 some of the provincial academies (Confucian centers of learning) were converted into modern schools or colleges and their books provided the nucleus of many provincial library collections. In 1902, following the Boxer Rebellion, Luo Chenyu called for the establishment of libraries at the national, provincial, and district level. He further recommended acquisition of Western and Japanese, as well as Chinese materials. ${ }^{3}$

At about the same time, the missionary Mary Elizabeth Wood began a process which led to the establishment of a library at Wuchang (now Wuhan in Hubei Province), the Boone Library School (China's first), and to the decision of President Theodore Roosevelt to allot part of the U.S. Boxer Rebellion Indemnity payments for library development in China. The Confucian Examination System was abolished in 1905, the same year that the first of many provincial libraries was established in Hunan. 4

Several factors were important influences for the growth and development of libraries during the second period of library development 
(1911-1949). The greatest change was the end of Imperial China and the establishment of a Republican government. This political change invited more liberal thoughts and ideas including Western influences. Some public libraries were established in 1912 from donations. These were ill housed and inadequately supported but were a first step in the development of public libraries. 5 In the 1930's smaller libraries were developed throughout China. By 1936, at the peak of the movement, there were 4,041 libraries throughout the whole country. Of these there were 502 independent libraxies and 2,543 school libraries. 6 These types of libraries were different in nature from those in Imperial China, where library resources were available only to the scholars.

The Japanese Occupation of China from 1937 was responsible for great destruction and the removal of libraries from the eastern part of China where many large and important university centers and cultural centers were located. After the war, the Library Association of China estimated that 2,500 of the collections had been lost (The total national university and college collection had been virtually halved from $5,500,000$ to $2,800,000$ ). According to statistics, there were only 940 libraries remaining by 1943 (between 1925 and 1936 the number of libraries had shown an eight-fold increase, from 502 to $4,041) .7$ With the defeat of the Japanese, the ensuing civil war between Nationalist and Communist forces led to the destruction of more libraries. Only 391 libraries remained in 1949, the eve of "liberation."8

The third period of library development covers the period of time since the establishment of the People's Republic of China in 1949. Historically, David Reith asserts in The Library as a Social Agency, ${ }^{9}$ the library has been in 
both substance and function, a holistic agency of society. While this is universally true, it has a great pertinence to the historiography of Communist libraries. In both official ideology and reality, libraries serve the highly politicized social life, far more securely than in the non-socialist nations. The library history and the history of the New China, therefore, have been intertwined.

The period since 1949 in China has indeed been marked by many drastic changes---changes that have been reflected in the way libraries have developed during that time in response to the prevailing societal conditions. Perhaps the most striking development is the way in which libraries have been directed to meet the political and economic needs of Communist China, with two main responsibilities emerging -- that of helping in the political indoctrination of the people, and of assisting in improving and increasing production. All the organizational, technical, fiscal, and physical changes of libraries are designed to serve these two ultimate purposes. There were times, such as the period between 1956 and 1958, when the libraries were urged to help increase productivity by making more science material available to researchers and the general public. There were also times, like those of the Cultural Revolution of 1966-1976, when "politics took command" and most cultural activities, including normal library work, were disrupted.

Therefore, in recounting library development in Communist China, I have divided the history of libraries into four periods of socioeconomic development of China: (1) the First Five-Year Plan; (2) the Second Five-Year 
Plan and prelude to the Cultural Revolution; (3) the Cultural Revolution; and (4) the Post-Revolution Open Door Policy.

The First Five-Year Plan: 1953-1957

Under the First Five-Year Plan libraries played an important role in the reconstruction of the nation. The objective of library service in this decade, in common with other economic and cultural endeavors, was "to readjust and consolidate, concentrate on essentials, raise both quality and quantity, and aim for steady progress." 10

Shortly after the founding of the People's Republic of China in 1949, strongly influenced by the Soviet model of development, those favoring a centralist bureaucratic approach to national planning implemented China's First Five-Year Plan in 1953. Soviet influence on Chinese libraries, in common with other areas of Chinese life, was predominant. Translations from Russian works on library science were popular and teaching materials were imported from the Soviet Union duty free, and so were Soviet experts, who flocked to China in droves. Lenin, father of the October Revolution, had stressed the importance of ideology and culture in imposing proletariat dictatorship. In this regard, he treated libraries as a means of mass education and indoctrination. This philosophy has profoundly influenced Chinese policies in library management. All these developments had important repercussions for libraries, which kept pace with and reflected the aspirations and needs of the times. The communists considered the library's practice of serving a small number of intelligentsia in the old days as "erroneous." The 
purpose of the library became now "to serve politics, production, workers, peasants, soldiers, and scientific studies."11

Following the Soviet example, the national library system in China was divided into three principal components:

1. Public libraries

2. Academy of Science libraries

3. Academic libraries

Each component has been developed and supervised by a branch of the Central People's Government. The public libraries under the Ministry of Culture are the major component of the national library system; the Academy of Science libraries are supervised by the Chinese Academy of Science, and academic libraries are supervised by the Ministry of Education. According to one statistic, at the end of 1956, there were 375 public libraries under the Ministry of Culture, plus 2,332 reading rooms attached to the cultural halls, 67 libraries in the Academy of Science system, and 225 academic libraries. The total collections numbered $106,625,462$ volumes. In addition to these libraries, there were about 10,000 libraries in teacher's colleges and schools under the supervision of the Ministry of Education. 12

In China, public libraries have played important roles in carrying out the revolutionary and political work of the Party. The tasks of the public library were outlined to include the following: (1) the propagation of ideology through the purchase, organization and utilization of printed materials; (2) the provision of assistance to smaller public libraries and other reading rooms to speed the development of local library service; and (3) the use of printed 
materials to serve the information needs of the party, government, institutions and enterprises in their area. To achieve these ends the libraries were exhorted to increase circulation, improve purchasing and processing, guide and assist readers, and compile bibliographies and indexes, especially of local materials. That public libraries were in need of development was attested by the fact that there were only fifty-five public libraries above county level in 1949.13 More recently, and signifying continued steady growth with reference to public libraries above county level, It was reported that there were 2,217 in 1984 and 2,344 in 1985.14

Libraries were used very effectively to spread and to promote Marxism and Maoism, which were the guidelines of human knowledge. For example, throughout the period of the Great Leap Forward the emphasis given to the works of Mao Zedong had a major impact on libraries. A nation-wide program of studying the thoughts of Mao began in 1959, peaked in 1960 and resurfaced at the end of 1965. Library involvement included a major meeting of twenty-one libraries in Beijing on "How to Learn and Spread the Works of Chairman Mao." The Beijing National Library established the first reading room devoted to "Publications and References on Marxism-Leninism and the Works of Mao." Following this model similar reading rooms were established in public libraries to promote the Maoist thought study program which extended into the early 1960s. 15

Books and other materials from library collections were used as media to accomplish the political and economic missions of the revolution and the Communists' ideology. Public libraries were used heavily to fulfill the 
function of distribution and promotion of government-controlled and approved information. They have been part of Communist China's important propaganda organization, established according to government policy, administered by governmental agencies, and financed through the governmental budget. They have served the people in general regarding the national socialization movement as the main policy for cultural affairs. The public libraries function at various levels: national, provincial, municipality, county, places of work (factories), and people's reading rooms in the rural areas as described below: 16

\section{The National Libraries}

The national libraries, especially those in Beijing and Shanghai, are considered as the cultural centers of the nation. They play an important leadership role in terms of providing nationwide public library services. At the end of 1978, the National Library of Beijing had over 9,800,000 books, magazines issues and other items. Since the founding of the People's Republic of China, the collections had increased sixfold--from 1,400,000. The National Library of Beijing, the only public library responsible for international publication exchange, had established exchange and gift relations with over 1700 institutions in 120 countries and localities. In 1978 it received from its exchange partners 54,785 items and offered itself $111,575.17$

\section{Provincial Libraries}

Governed by the provincial Cultural Bureaus, these libraries coordinate the activities of the public libraries in the respective provinces. The provincial libraries provide the next tier of library 
service. Their numbers increased between 1950 and 1952.18 They were given special attention as centers of local provincial library work, acting as central reference collections rather than circulating libraries. Collections began to grow. They were given a special responsibility for provincial history. They were open to the people, providing ready access to exhibition halls, and magazine, reference and children's reading rooms. 19 They maintained specialist staffs to organize mass cultural activity such as reading groups, exhibitions and other propaganda activities. The average collection size at the provincial level in 1950 was about 145,000 volumes. By 1952 this had risen by about a quarter. 20 The provincial libraries had the responsibility to assist county libraries in their respective provinces.

\section{County Libraries}

County libraries based on each county cultural hall, became responsible for guiding the village reading room to spread cultural and scientific knowledge and agricultural technology. 21 For example, by 1963 the priority given the agricultural sector led to the transfer of most agriculture books from public libraries to village and commune libraries to directly support the national agricultural policy. 22 With heightening political activity in 1964 and the propagation of the slogans "class struggle," "production struggle" and "practicing scientific experiments," libraries became involved in sending books to the "front line." The Shanxi Provincial Library alone sent 100,000 books to more than ten counties, cultural halls 
and many villages in support of these campaigns and "socialist education." 23 Eighty percent of China's population lived in villages. By 1956 there were 231 county libraries. Although not large, county libraries, usually run by two to three full-time staff members and with a targeted minimum collection of 3000 volumes, were nevertheless important information centers. 24

4. Municipal Libraries

Prior to 1949 the people of China's major cities had few real public library services. 25 Post-liberation municipal libraries were often established by the amalgamation of pre-existing smaller, private, and sometimes technical and scientific libraries. Two types of municipal libraries emerged. The first, in the larger metropolitan self-governing areas (Beijing, Tianjin and Shanghai), were more akin to provincial libraries. The second, in ordinary cities, were subordinate to the local provincial library. 26 In 1951 the average municipal library held 80,000 books and served about three hundred readers a day. Nevertheless, some held nearly a million books (e.g. Shanghai in 1952 had 9,000,000 and Qingdao held almost $816,000)$ ). 27 Being city-based, the municipal libraries were close to industrial and commercial centers. They tended to emphasize materials on economics, trade, industry and technology. Like their provincial counterparts they provided reading room accommodation, and educational and propaganda outreach services. These included extension work to factories, depots served by mobile vans, branch networks and group discussion meetings 
on topics such as increasing production and health schemes. Municipal libraries were to assist district libraries. 28 By 1956, on the rural outskirts of the three greater municipalities (Beijing, Tianjin and Shanghai), there were a total of twenty-one equivalent district libraries. 29

\section{Labor Union Libraries}

Labor Union Libraries were one of the most significant library developments during these years. The All-China Federation of Labor held a conference of Labor Union librarians in Beijing in September 1955 which decided the policy, planning, budget, organization, and the scope of activities of labor union libraries throughout the country. 30 Labor Union Libraries were run by the labor unions in the factories, mines and industry, intended primarily to propagate Marxism-Leninism-Maoism, to raise workers' political awareness, and to increase their knowledge in technology and production. A rapid expansion of such libraries occurred immediately after the conference. By the end of 1955, there were a total of 17,486 Labor Union Libraries with total holdings of 21 million volumes. By the end of 1958, the total number of such libraries was increased to 35,000 and their total holdings to 34 million volumes. 31 With the development of the cooperative movement in the farms, rural libraries, which often were reading rooms, sprang up rapidly. Their purpose was "to increase knowledge of the peasants, to popularize cultural and technological knowledge, to excite enthusiasm for production and 
to promote production." By the end of 1956, there were supposed to be 182,960 such libraries. The Revised Draft Program for Agricultural Development in 1956-1967, as designed by the Chinese Communist Party in 1955, called for the establishment of a basic cultural network in rural areas in seven to twelve years. 32 6. Village Reading Rooms The village reading room is the smallest library unit which carried out the three general library functions: political, economic, and educational. 33 They were generally guided by county or other public libraries, and organized by the local people and administered by local Party committees. They were the most basic unit in the total public library network. With guidance from the local public library--often the county library--three to five elected peasant volunteers ran the service on a daily basis. The libraries were usually housed in the local primary school, or cooperative. The lack of funds and dependence on voluntary staff made this tier of library service a weak link in the system. 34

\section{Children's Libraries}

These are specifically designed for children so that at a young age, the thoughts and ideology of Communism and Maoism can be introduced to them. Children's libraries were for the first time established in public libraries, either as special services in municipal libraries or, as in Beijing, Shenyang, Lanzhou and Shanghai, as independent services. They exist in various degrees at all levels of public library provision, from the Beijing Library 
Children's Reading Room to the children's cabinet in the reading room of the humble village cultural hall. Expanded publishing of children's materials tended to provide picture stories descriptive of the lives of "people's" heroes (i.e. model workers) and works on literature, history, natural science and other subjects. For example, during the Cultural Revolution, the policy on art and literature was represented shorthand by the slogan "literature and art serve politics." 35 This approach resulted in much formula writing which was at best ideologically fulsome. This applied at all levels but especially in the children's literature field, where young minds were to be molded. 36 In children's literature the political education dimension was emphasized almost exclusively. Fantasy, animals and folk tales were proscribed although towards the end of the period tales about Monkey from the classic Journey to the West began to reappear. 37 Stories were expressly directed towards political socialization. They were heavily ideological, dealt with immediate issues related to life, adhered to ideologically acceptable and often didactic themes (e.g. women's equality with men, minority peoples, sharing, cooperation, patriotism, internationalism, social injustices of the past, devotion to work and serving the people), lauded revolutionary heroes, praised resistance to foreign aggression, exalted the revolutionary overthrow of oppressors, and portrayed characters which were stereotyped. 38 
On the whole, the public library system in Mainland China developed quickly under government control. The China State Statistical Bureau in its Ten Great Years ${ }^{39}$ estimated that the number of public libraries had grown rapidly. In 1949 there were only 55 public libraries above county level while in 1958 there were 922 public libraries above the county level. Thus, it is safe to assume that the actual numbers of various types of public libraries now are even more substantial than those stated. More recently, and signifying continued steady growth with reference to public libraries above county level, it was reported that there were 2,217 in 1984 and 2,344 in 1985.40

In the development of the library system, the Soviet model exercised some major effects in the transformation of the nature of the collections. In all the libraries publications defined as reactionary, obscene or absurd were purged. Marxist-Leninist and Maoist works, which had been banned under the Guomindang days, were acquired on a large scale and so were popular reading materials. The government subsidized the acquisition of many scientific books published in 1937-1949, when, because of the Sino-Japanese War and the subsequent Civil War, libraries did not increase their holdings in any significant way. Library budgets and staffs were also increased. For example, in 1957 the budget for public libraries under the Ministry of Culture had increased by 372.3 percent over that of 1953 when the First Five-Year Plan was inaugurated, and the number of staff members had reached 3,714, more than twice that of 1950. Circulation seemed to be on the increase too. In the year of 1955, public libraries had a circulation figure of more than one million volumes. Besides, they established book mobile units or collective lending units to take books to readers' places of work. Among the 5,230,000 volumes 
circulated in this manner, 80 percent of the borrowers were workers, peasants and soldiers. 41

During this period, libraries of all types conducted study groups, exhibits, book talks, etc., to propagate political movements initiated by the government, such as the land reform, suppression of counterrevolutionaries, Resist-American and Aid-Korea campaigns. The use of the library for the distribution of Marxist literature had a tradition that preceded founding of Communist China. It was perhaps inspired by the practices of $\mathrm{Li}$ Dazhao (1888-1927), one of the founders of the Chinese Communist Party. Of this intellectual it has been observed: "Li---political theorist, literary figure, and librarian---played a vital role in the introduction of Marxism into Chinese society. During his tenure as head librarian at Beijing University, from 1918 until the mid 1920s, he utilized to its full measure the library's potential as a center for political activism. By directing the traditional functions of a university library (such as the systematic acquisition and distribution of materials and the utilization of space for private study, group discussions, and small seminars) towards the promulgation of Marxism, Li Dazhao organized enough support to begin China's journey towards revolution. $" 42$

The significance of Li Dazhao's work and model for Chinese librarianship is manifold. It has been outlined as follows, in general terms: 43 Libraries are to educate the people through the distribution of literature and the teaching of Marxist texts. They are to support socialist reconstruction and help guide the masses toward the attainment of communist society. 
Librarians are to diligently dedicate and commit themselves to the attainment of these ends as radicals increasingly knowledgeable both in the cultural and political domains. They are to impart this knowledge directly to people. Li has undoubtedly afforded Chinese librarianship a uniquely heroic model. $\mathrm{He}$ employed Mao Zedong as an assistant and influenced his conversion to Marxism. 44

Mao's work in the library has been kept at minimal profile in the official history as it was not at all a time of his pride and grandeur. However, its influence upon the forming of his mind frame should not be underestimated. First, that part of his life made him realize the power of knowledge, especially the significance of books for spreading ideological propaganda. 45 He developed his opposition to intellectual arrogance. Mao's suspicion of the intellectuals, of their ability to deal skillfully with abstract terminology far from the harsh realities of life, was ultimately to surface in his writings especially through his concern about the divorce of theory and practice. This ambivalence toward knowledge and the men of knowledge foreshadowed many of his political movements against the intelligentsia and the post-liberation management and control of access to knowledge and libraries. 46

As the Communist Party became the ruling party in the new China, the goals and objectives for libraries appeared to be more diversified than during the early era of revolution. What is unchanged though is the function of library as a tool of the party. In response to the call of the Chinese Communist Party for "marching toward science" in 1956, the Communist 
Party raised the cry "March toward the Sciences" and all libraries concentrated their efforts on building up their scientific and technical resources to support reference and research work. The same year launched the short-lived "Let the Hundred Flowers Bloom" movement, when citizens were encouraged to voice any criticism they might have of the regime. In its wake, however, the leadership of the state soon became paranoid and suspicious of ulterior motives on the past of the critics. In consequence, the movement came to an abrupt end in the following year, resulting in the repression of free expression among the intellectuals. What followed suit was an austere Anti-Rightist Movement during which innumerable people were thrown into prisons and labor camps to get a "reeducation." Many died from physical torture or suffered mental breakdown. The campaign heralded the recurrent political suppression of the dissidents in China.

By 1957, libraries were facing criticism. In response to the Conference on National Cultural Work of April in 1956, some libraries apparently had shifted gradually but markedly from their emphasis on service to the masses towards service to science and related research. Suggesting a shift in ideological emphasis by 1957, librarians found themselves out of step and under challenge for allegedly misinterpreting their role and ignoring service to the broad masses. The bourgeois viewpoint exhibited through the incorrect approach of service to elites was to be opposed and this ideological error was to be resisted. 47

University libraries were similarly challenged for emphasizing research over teaching needs. The change in emphasis signaled that the 
centralist bureaucratic approach to development was by late 1957 under pressure from proponents of the mass line. 48 University libraries in institutions of higher learning and research establishments were given three objectives: (1) To serve teaching staff and students; (2) To serve scientific researchers; (3) To propagandize Marxism-Leninism and the Chinese Communist Party's policies and decisions. 49 During the subsequent "antirightist movement" those "bad elements" within librarianship who opposed the Soviet model in the field and the service emphasis which catered principally to the broad masses were purged.50 For example, not all the librarians liked the Soviet influence on, and the Party's domination of, libraries. They held more traditional views about libraries and did not agree that libraries were to serve mainly the workers, the peasants, and the soldiers. Opposition within the profession was crushed.51 Thus we see the ending of a period of growth and planned development and the emergence of a trend which was ultimately to lead China into the radicalism of the Great Proletarian Cultural Revolution.

By the end of the First Five-Year Plan, China's libraries were better coordinated and more highly centralized than in 1952. Library funding and staffing levels had grown substantially. Furthermore, the level of circulation had expanded through more active dissemination techniques, which especially favored workers, peasants and soldiers. Library collections had generally expanded and were better organized, rationalized and restored. The Soviet model had been embraced and modified. Library policy, planning and purpose were thoroughly studied through national meetings and conferences and widespread professional discussion followed in the newly-born library 
literature. Science education and training were strongly stimulated to assist national development and library collections reflected this drive. A major program of bibliographic listing was begun. Library cooperation and coordination strategies and structures were developed and partially implemented, thus providing a basis for networking. The achievement was quite impressive.

The Second Five-Year Plan and Prelude to the Cultural Revolution: 1958-1965

As early as 1956 there were signs of strain and frustration in the Beijing leadership arising from an apparent division over methods of speeding up the pace of industrialization and modernization and from a growing disenchantment with the Soviet model. In March 1957 Mao called for a protracted struggle to defeat erroneous ideas and "revisionism." The antirightist movement began. The momentous program of the Great Leap Forward and the Communes launched in 1958 suggested a general shift leftward. Later in that year, as the Great Leap Forward took an economically disastrous turn and the Sino-Soviet rift (which had begun in 1957) grew, Mao gave up his control over the daily affairs of the state without relinquishing supreme authority. 52

The short-lived Great Leap Forward launched by Mao Zedong in 1958 attested to his commitment to voluntarism and reaffirmed Chinese selfreliance and self-assertion. Mao, impatient with the pace of development, hoped to mobilize the enthusiasm of the masses and thereby accelerate national construction. The radicals hoped to achieve what the centralist 
bureaucrats' emphasis on capital investment, routines, and gradualism could only reach toward. When celebrating the fortieth anniversary of the Russian October Revolution, Liu Shaoqi first advocated achieving "greater, faster, better and more economical results in building socialism."53 This slogan later became the keynote principle for the socialist construction, underpinning the Great Leap Forward. The Central Government began to promote economic prosperity.

Premier Zhou made a suggestion in an intellectual work meeting. He urged that librarians strengthen and improve library work and that the library undertaking be regarded as an essential prerequisite of scientific research because production and scientific research often demanded that the library contribute books and materials in time. Later the first session of the national library work meeting was held. Delegates discussed what to do next and made a decision: the library is both a propaganda organ and an educational and cultural institution as well as a research institution. They established a policy: the greater libraries of provinces and cities must serve scientific research. 54

Shortly thereafter, the State Council published The National Library Coordination Scheme. Under the guidance of the National Scientific Committee, the Library Group was founded. There were two National Central Library Committees (in Beijing and Shanghai) and nine regional central libraries (Wuhan, Shenyang, Nanjing, Guangzhou, Chengdu, Xi'an, Tianjin, Ha'erbin, and Lanzhou). These central libraries were to guide and assist the smaller libraries in their own areas, as well as coordinate the work of the major libraries. 55 For instance, in Beijing the responsibility for 
acquiring publications of capitalist countries is divided among several libraries, each specializing in a certain field. Apart from acquisition, the central libraries, both national and regional, coordinate such other library activities as compilation of union catalogs, interlibrary loans, and redistribution of books. Later on, library centers or coordination committees were also founded in some provinces. 56 The hierarchical structure of the Chinese system of libraries is charted as follows:

Figure I.

The Structure of China's Library System

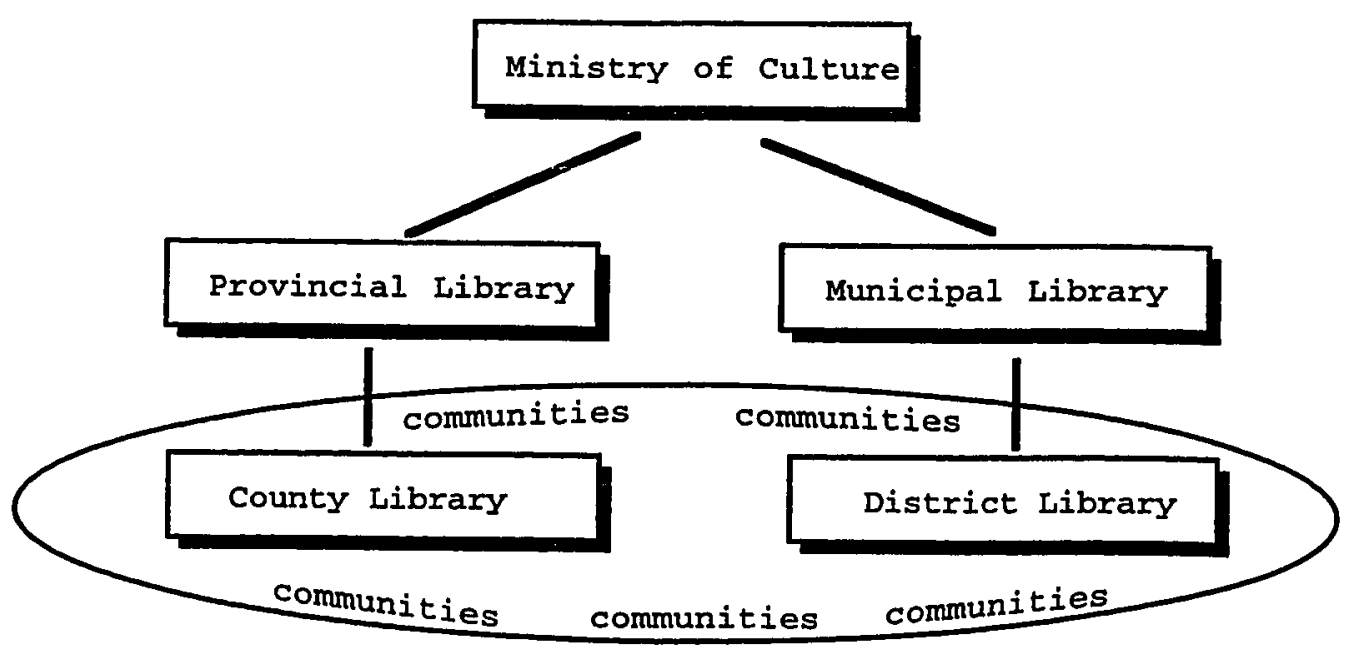

As shown in the Chart, vertically, large public libraries were instructed by the Ministry of Culture to help smaller ones under the jurisdiction of the same unit. Through book lending and other experimental projects, the provincial libraries had the responsibility to assist county libraries in their respective province, municipal libraries were to assist district libraries, and the county libraries were to assist those at lower level, and so on. Many small 
libraries worked hand in hand with local cultural halls, bookstores, and museums to form a cultural network in the villages. Public libraries were designated as coordination centers. Nanjing Library, for instance, organized all libraries in the three principal systems of the province of Jiansu according to their specialties. Larger libraries in one system were made to assist smaller ones in the same system. For instance, Nanjing Engineering College Library was made to assist technical school libraries and other libraries specializing in mining technology in the province.

Horizontally, local library coordination committees, composed of representatives from local libraries, met regularly to discuss problems of mutual concern. To train librarians, some libraries combined efforts to offer courses of library science in the so-called "politically red, academically expert" colleges, with experienced practicing librarians serving as part-time instructors. National bibliographies, union catalogs, indexes, etc., were being compiled; limited centralized cataloging and interlibrary loans were instituted. In some areas, a reader could receive a library borrowing card good for all the libraries in that area. In the spirit of cooperation, many large libraries shared their resources with their "brother libraries." For instance, libraries in Shanghai, a city which for many years had been the cultural and publishing center of China, transferred 500,000 volumes to help small libraries in six remote provinces, such as Jiangsu and Sinjiang. 57

Focusing on public libraries in 1958, the Ministry of Culture called for Great Leap Forward meetings. The first major meeting of the national, provincial and autonomous area library services was held in March 1958. 
The 33 libraries under the leadership of the National Beijing Library service enunciated a "Ten-Contest" proposal to challenge the librarians of the nation. These were contests in: (1) the circulation of books; (2) the attitude of service; (3) propagation of books; (4) book purchases and cataloging; (5) old book clearing and rearrangement; (6) in-service guiding and assistance; (7) interlibrary cooperation; (8) service innovation; (9) operating library with diligence and thrift; and (10) "red-and-expert."58 The contest was to be conducted despite proposed funding and staffing cuts of respectively, 25 and twenty-two percent. 59 The cuts were almost met. Further, services were to be expanded, hours extended, novel "active" book-delivery systems established, duplicates redistributed, backlogs eliminated, special reading rooms opened and services made available to new categories of users. To achieve these ends expediency was embraced, unacceptable staff were removed, and, it appears, standards were suspended. 60

Half a year later, all libraries of the Chinese Academy of Science held a meeting. Academic libraries, school libraries and libraries in many provinces also had their own meetings. Everybody was said to be very enthusiastic. The Academy of Science libraries were open to other agencies, and the number of readers increased dramatically. There was a 160 percent increase in collective group borrowers and a 337 percent increase in individual borrowers over the previous year. Many libraries were "creative" enough to find various means to get the books to the readers in the countryside, factories, restaurants, meeting places, barber shops and even public baths. One district library in Beijing established 412 circulation centers in half a year. 61 
According to reports published in China in 1959, under the principle of getting things done with the least amount of money, or even no money at all, libraries everywhere were supposed to utilize all their manpower and resources in the most efficient manner. Many of the backlogs were cleaned up and made available to readers. The Beijing Library, by using simplified cataloging, processed half a million duplicates. According to incomplete statistics, 33 public libraries at the provinciai and municipal level reduced their staff members by 21.8 percent and operating funds, 23.6 percent, and at the same time greatly increased their efficiency. The majority of the libraries were said to be open every day. 62

Also in 1958 the first public library was established in Qinghai, as well as Tibet. The provincial library at Jilin with a collection of 400,000 volumes opened its doors. Even more impressive was Ningxia. Before 1949 there was only one reading room with 4,000 volumes. Now in 1958, there were 11 public libraries at the county level with a collection of 259,521 volumes, 1,002 village libraries, 12,000 reading rooms with journals and popular magazines in factories and industries, and more than 3,000 college and school libraries. People in even the remotest places, it seems had facilities to read in and from which to borrow books. 63

Furthermore, numerous circulating libraries operated by the common people sprang up like mushrooms. For instance, in June 1958, one district in the City of Tianjin published the rules and regulations for governing this kind of library. Only one month later, at the end of July, 152 libraries were established in that district. According to a statistic compiled from 88 of the 152 
libraries, they had altogether a combined collection of 61,438 volumes and a volunteer staff of $\mathbf{2 3 2}$ members. In another county in Hebei Province, between May 1 and August 1, 1958, under the leadership of the local Party commissioner, a total of 174 libraries at various levels were founded and 83 old ones were restored. By June 1958, according to incomplete statistics, there were 35,659 commune libraries in the province of Henan alone, and 67,685 in Guangzhou. 64 Although all the figures came from unimpeachable official sources, the rosy picture sounds indeed too good to be true. One cannot but wonder how so many libraries could spring up in a matter of months. Did libraries really have such "unprecedented" achievements in China as claimed? In order to understand the real situation, we have to trace briefly the political developments in the country.

With the 1957 Anti-rightist movement, the "large character wall posters" appeared, and experts with the so-called wrong thoughts were persecuted. The slogan "Put Politics in Command" meant that education must serve proletarian politics and therefore must be combined with physical labor. Thought reform or ideological remodeling for intellectuals was necessary. Students and teachers were transferred randomly to non-academic jobs and classes became irregular. Students often read the Beijing Review. From then on, especially in 1961-62, all schools began to emphasize one's social and family background, instead of academic achievement. 65 Academically able students could not be admitted into universities if they had come from the wrong class and the wrong family. The Great Leap Forward set the economic targets so impossibly high that the only thing people could do was to fabricate figures. It thus started the bad practice of highly inflated 
figures and unrealistic claims. By the end of 1958, almost all of the rural populace had been incorporated into some 25,000 people's communes. The communes were intended to swiftly increase agricultural output by imposing military-like organization and labor-intensive projects such as dams and irrigation systems. Industrial output targets were revised upwards sharply, and localities established many small "backyard" factories to produce steel and other goods. Forests were felled to be used as fuel, which often disturbed the ecological balance. All these short-sighted "accomplishments" were reached so that officials could make impressive reports. 66

As a result, education, industry and agriculture all suffered setbacks. Libraries of course, could not escape the same fate. The ambition of the Great Leap Forward contained the seeds of its collapse. The situation for libraries was increasingly difficult. The apparent contradiction between proposed expansion of services and budgetary and staffing cuts of almost a quarter no doubt created tremendous difficulties for library management. The ongoing struggle between the two lines and the apparent tension between service to the masses and service to national construction must have unsettled many library workers and heightened confusion. The demands for heroic production targets undoubtedly led to fabrication in the compilation of production statistics.

Wu Weici from the library school at the University of Beijing has summarized the impact on libraries generally as follows: 1) The level of development proposed in the Great Leap Forward was beyond China's means. Targets were too high, operational practices were neglected and 
collections slipped into decline at least until 1962; (2) Emphasis on serving the masses meant a downgrading of support for scientific experts; (3) The destruction of old rules and regulations prior to the sound development of new alternatives left libraries without parameters and in chaos; and (4) Challenges by the radicals about 1960 on "capitalist library science" and accompanying purges eliminated personnel with considerable and much needed knowledge and experience. 67

Throughout the period of the Great Leap Forward the emphasis given to the works of Mao Zedong had a major impact on libraries. A nation-wide program of studying the thoughts of Mao began in 1959, peaked in 1960 and resurfaced at the end of 1965. Library involvement included a major meeting of twenty-one libraries in Beijing on "How to Learn and Spread the Works of Chairman Mao." The Beijing National Library established the first reading room devoted to "Publications and References on Marxism-Leninism and the Works of Mao." Following this model similar reading rooms were established in public libraries to promote the Maoist thought study program which extended into the early 1960s.

In September 1962 Mao first attacked "revisionist" tendencies in China. He was determined to resist China's succumbing to what he regarded as ideological and revolutionary decline of the kind which he believed had befallen the U.S.S.R. after the death of Stalin. Mao resumed his active leadership, delegated more power to his wife, Jiang Qing, and ushered in a period of renewed emphasis on ideology and on the thought and personality of Mao. In 1963 Jiang Qing began to dominate the cultural activities, and 
scholarly and professional journals were suspended one after another. The leaders shifted still further leftward in 1964, with a violent attack on those with allegedly "capitalist" and "revisionist" leanings, in tones that anticipated the Cultural Revolution. 68

The ongoing literary debate was important insofar as literature and art policy provided a major battleground for the protagonists in the two-line struggle. Interest in the debate grew in 1962 following a re-airing of the "Yanan forum" talks on art and literature in newspapers and periodicals, and in 1963 after the Third National Conference of the All China Federation of Literature and Art held at Beijing. Writers, exhorted to learn through the feelings and experiences of the masses, were sent to villages and factories to receive their socialist education. According to the ideological interpretation current in 1963, "real" art could only emerge through the "real" life of the masses. Illustrating the strength of this program, in the northeastern provinces alone, 4,000 artists were soon living among the peasants. 69 This trend was to be taken much further during the Cultural Revolution which began in 1966.

The debate on art and literature was more than theoretical discussion; it affected libraries profoundly. The policy determined priorities for libraries in terms of clientele to be served, materials to be purchased, distributed or censored, management approaches and categories of library services to be favored. As a period of accelerating struggle between the two lines, the early 1960 s included the socialist education campaign; a rectification campaign for intellectuals, including librarians; and rumblings against "revisionists" and 
"capitalist roaders," even in the party itself. By 1965 the groundwork was laid for the Great Proletarian Cultural Revolution, the apparent ultimate struggle between the two diverging lines, which was perhaps the most difficult and disastrous period for libraries. Indeed, in the climate of ideological conflict which characterized the early to mid-1960s, librarianship was, not surprisingly, unsure of its direction. 70

\section{The Great Proletarian Cultural Revolution: 1966-1976}

The thunderstorm of the Great Proletarian Cultural Revolution began in 1966 and continued until 1976. The Great Leap Forward was an original Chinese developmental strategy. Its failure, aside from causing severe economic dislocation, was a watershed for the system, marking a major defeat which led to uncertainty, self-doubt and a lack of leadership consensus. Resistance emerged in the mid-1960s in some quarters as the centralist bureaucrats regained control. Fearing that the gains of the revolution were being progressively undermined, Mao and other radical figures resisted the program of former President of the Republic, Liu Shaoqi. It was observed that the Great Proletarian Cultural Revolution (GPCR) represented a major and perhaps the last effort by the Maoists to impose their economic development and national defense strategies on China. As during the Great Leap, the Maoist attempt to shift the center of gravity of decision-making authority over resource allocations and pace of development away from the central and upper level bureaucracy down toward "the masses" resulted in widespread disruption of established bureaucratic processes and a temporary setback to overall production. 71 
Under Mao, the extremists also ignored economic laws. Out of touch completely with economic reality, they confused management with ownership and tried to use political ideology and class struggle to promote economic reform. They disregarded the established policy that one should be rewarded in accordance with one's contribution, but put into practice the socalled "equalism." As a result, workers did not work but just exaggerated their production figures. The country's economic development was disrupted. Furthermore, the extremists despised knowledge and the intellectuals who use their brains instead of their bodies. They regarded intellectuals as capitalists and labeled them the "stinking Number Nines" i.e., the lowest level even among the undesirables, lower than the landlords, the rich farmers, the counter-revolutionists, the bad elements, the rightists, the traitors. They did not try to upgrade the laboring class, but tried to eliminate the difference between the laboring class and the intellectuals by forcing the latter to use their hands only, thus greatly hampering scientific and cultural development in China. 72

Following Mao's instructions that class struggle had to continue perpetually in order to sustain revolutionary fervor, young radicals searched the country for remnants of "bourgeois" ideology and "revisionism" and without scruples destroyed whatever appeared objectionable to them. Their chief targets were the old revolutionary leaders of the moderate faction within the Party, and the old civilization. The old civilization was specified as the "four olds"--old ideas, old culture, old customs, and old habits of the "exploiting classes." To achieve their goal they were urged to "totally topple, smash, and expose counter-revolutionary revisionists, the bourgeois rightists, 
and reactionary bourgeois academic savants," who "must never be allowed to rise again!"73

The period had considerable impact on Chinese library and information services. On the broad ideological front, libraries during the Cultural Revolution period were assigned clear political purposes. They were to serve the practical struggle, put politics in command, integrate practice and theory, embrace self-reliance, apply the open door and pursue the dictatorship in culture. Advancing beyond the political sloganeering of the era, libraries applied these precepts in myriad ways. At the very beginning of the Cultural Revolution when politics took command, normal library activity was widely curtailed. 74

Libraries, as storehouses and disseminators of literature, enjoyed no immunity in this climate. The artistic dimension of the Chinese literature produced both for adults and children was narrowly defined. Literary works on model workers were noted previously. In children's literature the political education dimension was emphasized almost exclusively. 75 Stories were expressly directed towards political socialization. They were heavily ideological, dealt with immediate issues related to life, adhered to ideologically acceptable and often didactic themes (e.g. women's equality with men, minority peoples, sharing, cooperation, patriotism, internationalism, social injustices of the past, devotion to work and serving the people), lauded revolutionary heroes, praised resistance to foreign aggression, exalted the revolutionary overthrow of oppressors, and portrayed stereotypical characters. 76 All books and publications that might inspire independent 
thinking had to be burnt or stashed away forever so that a new generation, blind and pliant tools of their leaders' will, might be born. Almost all the classical heritage of China, as well as that of the West, was marked for extinction. All intellectuals were condemned as careerists," "freaks and monsters," "exploiters and intellectual aristocrats."77

A large number of books that were regarded as feudal, capitalistic or revisionist were sealed up or burnt. A "book famine" developed in society. By rough estimate, in the forty-one county libraries of Fujian Province, there were 464,964 volumes of books in 1966 , but 224,023 volumes were burnt and lost, many of them rare books. Another example occurred in Hubei Province, Jingchow district, where 400,000 volumes of books and journals in seven county libraries were destroyed. These accounted for half of the total book stock. By rough estimate, libraries at the county level and above were probably reduced by one third.78

Politics demanded that many libraries be closed, many until 1972. Their role, purpose, staff and collections were suspect. The extremists could not allow the library to be "the paradise of the capitalist class." In 1970 it was reported that "for exactly five years, many libraries were closed and had no new acquisitions."79 Shanghai Library was closed from 1967 to 1970 . Even after it re-opened its doors in 1970, the card catalogs and most of its Chinese books, except for a small number containing "correct thoughts"' were offlimits to the general reader. 80 The Western-languages section was nominally open, but no one dared to use it for fear of being labeled "admirers of the West, and trucklers to foreigners." Even scientific and technological books 
published before the Cultural Revolution were banned. No book could be checked out. Few readers ever came to the library, since everyone had the works of Marx, Lenin and Mao at home. 81

Academic libraries suffered even more than public libraries. During 1966-1968, education had been undergoing radical transformations. In fact, it was something close to an "Educational Revolution," which has affected colleges and universities, including libraries, and is considered as still being in an "experimental stage" undergoing continuous study and evaluation.

Two directives of Mao Zedong had a profound impact upon educational policies. One, issued on May 7, 1966, called for peasants to increase their political, cultural, and military knowledge. The other, from July 21, 1968, called for college students to be selected from workers and peasants with practical experience. The number of worker colleges, set up in factories and other places of work, and peasant colleges, set up in the rural areas, increased dramatically after the Fourth National People's Congress in January 1975, which set high economic targets for the nation. Such types of colleges provided the means for the speedy acquisition of technical knowledge through short-term training classes lasting from several months to one or two years. In Shanghai alone the number of workers' colleges increased in 1975 from 360 to 1,200. The emphasis was on training in practical skills and also in some languages so as to be able to read technical information. The teachers were workers, technicians, professionals, or college teachers. 82 
This increase in learning activities outside established institutions had an impact on the library services provided by these institutions and required innovative solutions for new needs. This also agreed with the concept that the whole society is a classroom and that the learning process is no longer confined to institutions but is a life-long experience. Under the new enrollment policies for academic institutions, students were taken from the countryside, factories, or army, where prior to attending college they had worked at least a couple of years after graduating from high school.

As the students, now composed solely of workers, peasants and soldiers, took command, they called for short and relevant courses, and spent their energy "making revolution," knowledge, technological know-how, and publications all became targets of scorn. Libraries which served instructional and research needs were accused of being "centers of feudalism, capitalism and revisionism," "tools of bourgeois intellectuals for the control of the school," "scenes of crime where bourgeois intellectuals achieve their fame," and "weapons of imperialist aggressions in China." In short, they were doomed to destruction. Many libraries with a long history and good collections were thus closed. Under the pretext of saving foreign exchange from being spent on useless materials, subscriptions to foreign periodicals were suspended. 83

Librarians were all labeled "watch dogs" of imperialists. 84 All but two library schools were suspended. Even in these two universities -- Beijing and Wuhan -- there were few students who dared to study library science, which was regarded by the extremists as of no use. There actually was not much that 
could be taught, because students were not allowed to study about libraries in any period or any country. Many librarians were persecuted or forced to change jobs. 85

At the end of the Cultural Revolution, when college entrance exams were reinstated in 1977, the university libraries were reopened and have since resumed their vital role in the educational process. The libraries are open now but there is still about a ten-year gap in the book and periodical collections, especially in the category of Western science and technology.

The following passage from a recent article in a Chinese periodical gives a general picture of these evil days for libraries in the whole country:

Because of wanton destruction by Lin Piao and the Gang of Four, many libraries were undermined, and their staff members exiled to the countryside. The collections which had been accumulated over a period of many years in some libraries were either carried off, robbed, or burnt. Our nation's libraries were subjected to destruction on an unprecedented scale. In 1965 , before the Cultural Revolution, there were 1,100 public libraries at or above the county level. After eleven years, instead of increasing, the number decreased by one-third. Similar situations can be found in libraries of other systems. Academic and labor union libraries suffered even worse devastation. So, during the Culture Revolution, the history of our libraries was not one of stagnation, but one of enormous devastation and retrogression. Because of the years of consistent disruption by the Gang of Four, of the hundreds of thousands of nationalized industries and other enterprises, very few could keep their union libraries open and operative. 86

Library networking was paralyzed. The libraries of the Chinese Academy of Sciences were prevented from offering effective service and their systems were severely weakened. Furthermore, professional 
library workers (experts) were criticized and sent from their libraries to rural areas to engage in and learn from productive labor.

In 1976 Mao Zedong died, the radical leadership (Wang Hongwen, Zhang Chunqiao, Yao Wenyuan and Jiang Qing) were arrested, and a nationwide purge of the radical left began, sometimes carried out by troops. By the end of 1976 the Great Proletarian Cultural Revolution had been brought to an end and the radical line was in decline. Those ideological structures which had projected librarianship along a radical and contracting course were in the process of being dismantled. The perceived extremes of politics had been tempered but the command position of politics personified through the Party remained the fundamental foundation of the state. 87

The Post-Revolution Open-Door Policy: 1976 to the Present

After the Cultural Revolution which ended in 1977, the political and economic situation in China began to change. The leadership changed the goal from political campaigns with class struggles to extensive economic revitalization. The objectives under the term of the Four Modernizations were set up to catch up with economic level of developed countries.

Since 1977, especially after 1979, support for library development has taken a new favorable turn. The requirement for books and materials increased tremendously along with the development of the country's production, scientific research, education and culture. The Central Government pays great attention to library work and states that different types of libraries should develop in all parts of the country and a network of 
libraries must be established to serve scientific research and the broad masses of the people.

To meet the demand of the nation, dedicated librarians have worked hard to pick up the pieces. In libraries that survived the disaster of the Cultural Revolution, catalogs and collections are again available to the public. Reader services have been expanded, and opening hours extended in many libraries. Local library coordination committees in large cities are meeting regularly again. Large libraries, such as the National Beijing Library and Shanghai Library, again shoulder the responsibility of providing reference and bibliographic service to other libraries, preparing exhibits, offering photo duplication service, extending interlibrary loans, etc. Beijing Library, being the national library, is once again responsible for centralized cataloging and providing catalog cards for new books to libraries in the nation. It now exchanges publications with 2,000 libraries in 120 countries, including the Library of Congress. Contacts with foreign libraries are being increased and strengthened. Many activities, such as the compilation of national and other union catalogs, special or subject bibliographies, and indexes, have been resumed. The Academy of Science Library is now in charge of the planning and operations of computerized scientific information retrieval. Library science journals have been revived, and the China Society of Library Science was founded in 1979.88

From now on, a large number of county libraries and branches will be established gradually. Children's libraries in all districts of the medium-sized cities will be given top priority. For this reason, the State Council has 
increased national funds to develop library programs. The buildings of the National Library of Beijing are being extended. The new building is one of the projects of modernization and will soon be under construction. In universities, the specialties of library and information science will make further advances. Vocational high schools of library science will be established. The library's scientific research will be further strengthened. The talents of library staff will be improved as soon as possible.

There has been a rapid increase in the number of public libraries at the county level and above. These libraries not only recovered from the effects of "the Great Cultural Revolution" but have greatly expanded their collections through acquisition of materials.

In 1979, the outlay of funds for the public libraries all over the country registered an increase of 40 percent over 1976. The number of public libraries reached more than 1700 and the collections amounted to more than $210,000,000$ items. In 1980, the circulation of books from public libraries all over the country amounted to $110,000,000$ and the number of library users reached $90,000,000$. The circulation of books from the National Library of Beijing amounted to $1,200,000$, and the number of readers was 530,000 , an alltime high since the founding of the country. 89

It is important for librarians that the Chinese Academy of Science developed a "Trial Regulation" about the determination of the titles of professional positions in library and information institutions of the academy of science system (such as research fellow, associate research fellow, assistant research fellow, research practice fellow, and management fellow) in 
November 1978. In December 1978, the Ministry of Education worked out a similar "Trial Regulation" for academic libraries. Now, both of them have been put into effect. This is the first time in the history of Chinese libraries that such a system of position classification has been implemented. Looking to the future, support for programs in China should leap forward. 90

In short, the national policy has changed. Libraries once again are performing functions that are no longer so centrally controlled. With the advent of the Open-Door Policy, a more positive approach and active attitude towards Western civilization has been adopted. This policy has changed the roles and functions of library and information services enormously. Libraries and information centers are becoming important parts of society, improving the intellectual level of the whole nation, serving the economic and political reforms, and meeting the needs of the modernization drive. As a popular Chinese slogan says, "it is a period full of challenges and opportunities."

Demands for well-trained and qualified librarians and information specialists are immense. Information technology and its applications in library and information services in China have not only challenged library and information science educators, but also created many opportunities to reform professional education. 


\section{Notes}

${ }^{1}$ Chao-hua Xie, ed., Zhongguo Tushu He Tushuguanshi (History of Chinese Books and Libraries) (Wuchang: Wuhan University, 1987), 4. 13.

2Steven Dahl, History of the Book (New York: Scarecrow Press, 1958),

3Polly-Ann Brumley Proett, "A History of Libraries in the People's Republic of China" (Ph.D. diss., George Washington University, 1974), 6-7.

4Fu-tsung Chiang, "A Historical Sketch of Chinese Libraries," Philobiblon 2(2): 1-6 (March 1978): 21-26.

5Leslie T. C. Kuo, "Communist China: Restoration and Expansion," Library Journal 87(20) (November 15, 1962): 4133-4136.

6Chi Cheng, "Libraries in China Today," Libri 9(2) (1959): 105-110.

7China (1949-1958) State Statistical Bureau, comp. Ten Great Years (Beijing: Foreign Language Press, 1960), 205.

${ }^{8}$ China Handbook Series--Culture, compiled by the China Handbook Editorial Committee (Beijing: Foreign Languages Press, 1982), 73.

9David Reith, "The Library as a Social Agency," in The Library in Society ed. Robert A. Rogers and Kathryn McChesney (Littleton, Colorado: Libraries Unlimited, 1984), 5-16.

10Encyclopedia of Library and Information Science, 1968 ed., s.v. "Library Development in Communist China."

${ }^{11}$ Lee-hsia Hsu Ting, "Chinese Libraries and Library Education, 19491980: Truth and Myth in the People's Republic of China," paper presented at the 100th annual conference of the American Library Association, 29 June 1981, 1-28, EDRS, ED 214516, microfiche.

${ }^{12}$ Quan Ying, "How to Evaluate the Development of Chinese Library Service," Tushuguan Gongzuo (Library Work) no. 8/9 (1957): 4-7. 
13X. Luo, "Management Development and its Practice in Chinese Library and Information Services." International Library Review 17(2) (April 1985): 129-149.

14"The Public Library Undertaking Prospers Day by Day," Guangming Ribao (Enlightenment Daily) (Beijing), 15 May 1989.

15John Barclay, The Seventy-Year Ebb and Flow of Chinese Library and Information Services: May 4, 1919 to the late 1980s (Metuchen: The Scarecrow Press, Inc., 1995), 78.

16Encyclopedia of Library and Information Science, 1968 ed., s.v. " "Libraries in the People's Republic of China: Public Libraries."

17George Chandler, "The Chinese Library System," International Library Review 12 (October 1980): 393-427.

18T.C Peng, "New China's Libraries," China Reconstructs 5 (September-October 1952): 40-48.

${ }^{19}$ Encyclopedia of Library and Information Science, 1968 ed., s.v. " "Libraries in the People's Republic of China: Public Libraries."

20John Barclay, The Seventy-Year Ebb and Flow of Chinese Library and Information Services: May 4, 1919 to the late 1980s (Metuchen: The Scarecrow Press, Inc., 1995), 25-26.

21Chang-pin Wang, "Tantan Sheng Tushuguan Wei Nungye Fuwu de Gongzuo," (A discussion of the Service of the Libraries for the Agriculture) Tushuguan (Libraries) 3 (September 1963): 4.

22-Fu-chi Chien, "1964 Nian de Guangrong Renwu, Touru Shin de Zhandou Shelun," (Editorial: the glorious task of 1964: start a new struggle) Tushuguan (Libraries) 1 (March, 1964): 1.

23Julia Wang, A Study of the Criteria for Book Selection in Communist China's Public Libraries (Hong Kong: Union Research Institute, 1968), 36. 
${ }^{24}$ Hung Chun, "Dui Xian Tushuguan Gongzuo Zhong de Wenti de Yijian," (Opinions on the issues concerning the county libraries) Tushuguan Gongzuo (The Library Work) 12 (December 1957): 32.

$25 Y \mathrm{Hu}$, "China's Four Modernizations and Library Service," paper presented at the IFLA General Conference, 1983, 5.

${ }^{26}$ Cheng-ching Lu, ed., Tushuguan Xue Cidian (The Dictionary of Library Science) (Beijing: Commerce Press, 1958), 56.

27T.C. Peng, "New China's Libraries," China Reconstructs 5 (September-October 1952): 44-48.

${ }^{28}$ Cheng-ching Lu, "Tushuguan Shiyeshi," (The History of Libraries) Tushuguanxue Tongxun (Bulletin of the Library Science) 2 (My 1963):37.

${ }^{29}$ Julia Wang, A Study of the Criteria for Book Selection in Communist China's Public Libraries (Hong Kong: Union Research Institute, 1968) 30.

30Y Cui, "Zhongguo de Tushuguan Gongzuo," (Communist Chinese Library Work) Ziguo Zhoukan (Ziguo Journal) no. 6 (November 1961): 12-15.

31Zongzhong Huang, "Libraries in New China during the Past Three Decades," (in Chinese) Wuhan Daxue Xuebao: Zhexue Shehuikexue Ban (Bulletin of Wuhan University: Philosophy and Social Sciences) 2 (1979): 22845.

32"Woguo Shinianlai de Tushuguan Shiye," (Libraries in China During the Past Ten Years) by the Section of the History of Library in Beijing Daixue Xuebao (Journal of Beijing University) 18 (October 1959): 96.

33Jen-min Kung, "Shi Tushuguan," (Municipal Libraries) Wuhan Daxue Renwen Xuebao (Journal of humanities of the Wuhan University) no.3 (1969): 2.

${ }^{34}$ Encyclopedia of Library and Information Science , 1978 ed., s.v. "Public Libraries, Fast East, People's Republic of China." 
35 V. Nee, "The Political and Social Bases of China's Four Modernizations," Columbia Journal of World Business 14 (2) (Summer 1979): 23-32.

36P. Krasilovsky, "What Chinese Children Read," Publishers Weekly 203 (9) (February 1973): 100-101.

37T.A. Zanielly, "Flowers in Full Bloom: the Variety of Chinese Children's Literature," Children's Literature 7 (1977): 181-190.

38"Children's 'Books from the New China," in Racism and Sexism in Children's Books, (London: Writer's and Reader's Publishing Cooperative, 1979), 101-106.

${ }^{39}$ China (1949-1958) State Statistical Bureau, comp., Ten Great Years (Beijing: Foreign Language Press, 1960), 205.

40"The Public Library Undertaking Prospers Day by Day," Guangming Ribao (Enlightenment Daily) (Beijing), 15 May 1989.

41 Allen Kent and others, eds. Encyclopedia of Library and Information Science (New York: Marcel Dekker, 1977), s.v. "The History of Libraries in China," by W.S. Wong.

42D.M. Nelson and R.B. Nelson, "The Red Chamber," Lournal of Library History 14(2) (Spring 1979): 121-128.

43D.M. Nelson and R.B. Nelson, "The Red Chamber," Lournal of Library History 14(2) (Spring 1979): 121-128.

44John Barclay, The Seventy-Year Ebb and Flow of Chinese Library and Information Services: May 4. 1919 to the late 1980s (Metuchen: The Scarecrow Press, Inc., 1995), 9.

45S. Kirkes, "Mao as Library User and Worker: How Early Experiences in Traditional Chinese Libraries Contributed to Mao's Revolutionary Ideas," American Libraries 7(10) (November 1976): 628-631. 1950), 154.

46R. Rayne, Mao Zedong, Ruler of Red China (New York: Schuman, 
47Shu-chi Wang, "Gonggong Tushuguan Gongzuo," (the Work of Public Libraries) Tushuguan Gongzuo (The Library Work)3 (March 1957): 40.

48"Chinese Communist Library Service in the Past Decade," Union Research Service 19 (8 and 10) (April and May 1960): 106-115 + 131-149.

${ }^{49} \mathrm{~A} \mathrm{~W}-\mathrm{T}, \mathrm{Ng}$, "Library Development in the People's Republic of China, 1949-1960" (Thesis, F.L.A., London: The Library Association, 1976), 10.

50 Chinese Communist Library Service in the Past Decade, Union Research Service 19 (8 and 10), (April and May): 106-115+131-149.

51 Lee-hsia Hsu Ting, "Chinese Libraries and Library Education, 19491980: Truth and Myth in the People's Republic of China," paper presented at the 100th annual conference of the American Library Association, 29 June 1981, 1-28, EDRS, ED 214516, microfiche.

52Lee-hsia Hsu Ting, "Library Services in the People's Republic of China: A Historical Overview," The Library Quarterly 53:2 (April 1983) :134160.

53 Shaoqi Liu, "Qingzhu Sulian Shiyue Shehuizhuyi Geming Sishizhounian Shengde Jianghua," (Speech at the Meeting Celebrating the Fortieth Anniversary of the Russian October Revolution of Socialism) Renmin Ribao (People's Daily) 7 November 1957.

${ }^{54} \mathrm{Ke} \mathrm{Du}$, "A Preliminary Probe into Establishing a Network of Libraries in Our Country," (in Chinese). Tushuguanxue tongxun (Bulletin of the Library Science) no. 1 (June 1979): 22-26.

55Wei-ci Wu and Shu-hua Zhang, "A Record of Chinese Librarianship in the Past Thirty Years," Tushuguan Gongzuo (Library Work) no.2 (May 1978): 4-9.

56Lee-hsia Hsu Ting, "Chinese Libraries and Library Education, 19491980: Truth and Myth in the People's Republic of China," paper presented at the 100th annual conference of the American Library Association, 29 June 1981, 1-28, EDRS, ED 214516, microfiche. 
57Guojun Liu, "Libraries in New China: a Survey of the Past Ten Years," (in Chinese) Beijing Daxue Xuebao (Bulletin of Beijing University) no. 18 (October 1959): 93-107.

58"Chinese Communist Library Service in the Past Decade," Union Research Service 19(8 and 10) (April and May 1960): 106-115+131-149.

59 "National Library Work Conference Concludes," translated in Survey of China Mainland Press No. 1745 (April 1958): 16-17.

60John Barclay, The Seventy-Year Ebb and Flow of Chinese Library and Information Services: May 4, 1919 to the late 1980s (Metuchen: The Scarecrow Press, Inc., 1995), 57.

61 Allen Kent and others, eds. Encyclopedia of Library and Information Science (New York: Marcel Dekker, 1977), s.v. "The History of Libraries in China," by W.S. Wong.

62Guojun Liu, "Libraries in New China: a Survey of the Past Ten Years," (in Chinese) Beijing Daxue Xuebao (Bulletin of Beijing University) no. 18 (October 1959): 93-107.

${ }^{63}$ Guojun Liu, "Libraries in New China: a Survey of the Past Ten Years," (in Chinese) Beijing Daxue Xuebao (Bulletin of Beijing University) no. 18 (October 1959): 93-107.

${ }^{64}$ Lee-hsia Hsu Ting, "Chinese Libraries and Library Education, 19491980: Truth and Myth in the People's Republic of China," paper presented at the 100th annual conference of the American Library Association, 29 June 1981, 1-28, EDRS, ED 214516, microfiche.

65Zongzhong Huang, "Libraries in New China during the Past Three Decades," (in Chinese) Wuhan Daxue Xuebao: Zhexue Shehuikexue Ban (Bulletin of Wuhan University: Philosophy and Social Sciences) 2 (1979): 22845.

66 Lee-hsia Hsu Ting, "Chinese Libraries and Library Education, 19491980: Truth and Myth in the People's Republic of China," paper presented at the 100th annual conference of the American Library Association, 29 June 1981, 9, EDRS, ED 214516, microfiche. 
67John Barclay, The Seventy-Year Ebb and Flow of Chinese Library and Information Services: May 4, 1919 to the late 1980s (Metuchen: The Scarecrow Press, Inc., 1995), 81.

68John Barclay, The Seventy-Year Ebb and Flow of Chinese Library and Information Services: May 4, 1919 to the late 1980s (Metuchen: The Scarecrow Press, Inc., 1995), 53.

${ }^{69} \mathrm{Julia}$ Wang, A Study of the Criteria for Book Selection in Communist China's Public Libraries (Hong Kong: Union Research Institute, 1968) 30.

70 John Barclay, The Seventy-Year Ebb and Flow of Chinese Library and Information Services: May 4, 1919 to the late 1980s (Metuchen: The Scarecrow Press, Inc., 1995), 55.

71W.W. Whitson, "China's Quest for Technology," Problems of Communism 12(4) (July-August 1973): 16-29.

72L. L. Wang, "The Library on the Chinese Mainland," Issues and Studies 13(1) January 1977): 91-106.

73 Robert S. Elegant, Mao's Great Revolution (New York: World Publishing Co., 1971) 205.

${ }^{74}$ J. T. Ma, "Libraries in the People's Republic of China since 1949," Wilson Library Bulletin 45(10) (June 1971): 970-975.

75T. A. Zaniello, "Flowers in Full Bloom: the Variety of Chinese Children's Literature," Children's Literature 7 (1977): 181-190.

76J.C. Giblin, "A Green Heart: Notes on Children's Cultural Activities," The Horn Book Magazine 51(6) (December 1975): 564-570.

77R. Stones, "An Introduction to Children's Books in the People's Republic of China," Bookbire 15 (1) (1977): 8-18.

${ }^{78}$ George Chandler, "The Chinese Library System," International Library Review 12(4) (1980): 393-427. 
${ }^{79}$ Encyclopedia of Library and Information Science, 1978 ed., s.v. "The People's Republican Period."

${ }^{80}$ D. A. Kelly, "At Last, an Arena: Current policies in Chinese Social Science," The Australian Journal of Chinese Affairs no. 2 (July 1979): 123-136.

${ }^{81}$ Encyclopedia of Library and Information Science, 1978 ed., s.v. "The People's Republican Period."

82Lee-hsia Hsu Ting, "Chinese Libraries and Library Education, 19491980: Truth and Myth in the People's Republic of China," Paper presented at the 100th annual conference of the American Library Association, 29 June 1981, 1-28, EDRS, ED 214516, microfiche.

${ }^{83}$ Ding Yuan, "Shift the Focus of Library Service to Socialist Modernization," (in Chinese) Tushuguanxue Tongxun (The Bulletin of Library Science) no. 1 (June 1979): 2-12.

${ }^{84}$ Ding Yuan, "Shift the Focus of Library Service to Socialist Modernization," (in Chinese) Tushuguanxue Tongxun (The Bulletin of Library Science) no.1 (June 1979): 2-12.

85Zongzhong Huang and Qiyu Zhang, "Education in Librarianship: Retrospect and Prospects," (in Chinese). Tushuguanxue Tongxun (The Bulletin of Library Science) no. 5 (September 1980): 16-25.

${ }^{86} \mathrm{Ke} \mathrm{Du}$, "A Preliminary Probe into Establishing a Network of Libraries in Our Country," (in Chinese) Tushuguanxue Tongxun (The Bulletin of Library Science)no. 1 (June 1979): 22-26.

87O. E. Clubb, "China after Mao," Current History 73 (429) (September 1977): $49-53$ and 86.

88Lee-hsia Hsu Ting, "Chinese Libraries and Library Education, 19491980: Truth and Myth in the People's Republic of China," Paper presented at the 100th annual conference of the American Library-Association, 29 June 1981, 1-28, EDRS, ED 214516, microfiche.

${ }^{89}$ Guangming Ribao (Enlightenment Daily) (Beijing), 15 May 1981. 
90Sun Yang, "Library Education in 2000," in Research Materials in Chinese Librarianship (in Chinese). (Beijing: China Society of Library Science, 1984),18-25. 


\section{Chapter III}

\section{LIBRARY EDUCATION IN COMMUNIST CHINA}

China has a population of more than one billion. It also has a vast library system. According to a report the 200,000 plus libraries of all types in China are staffed by more than 100,000 people, among whom only 2,000-3,000 are professional librarians. This figure demonstrates the serious situation of training too few in library science. This causes great pressure on library education. 1

At present, the education of library and information science has much in common among countries regardless of their social systems. One of its cardinal goals is to train and produce qualified personnel to address the issues generated by the demand for increasing information within a society. While this is the pressing task of the library education in China today, it has not been so in its long past.

In ancient China, the libraries were founded for the intelligentsia and official literati instead of the general populace. The administrative work was minimal compared to the modern system. Since the Ming Dynasty, for instance, libraries catered to the needs of scholars and students. Only a very few scholars or administrative staffers were needed for control, utilization and circulation of the books, paintings, or other written materials. 2

In the Nationalist Republic that replaced the collapsed dynasty in 1911, library staffs were composed of short-term trained staff and special 
professionals. With the passage of time, the regular education of professional library workers came into being, and underwent significant development. A number of universities established a library department with a view to developing the specialized personnel for library administration. 3

Since the founding of the People's Republic of China in 1949, libraries have served as an instrument of the broader political, cultural and ideological activities of the government in some of the most daring social and political experiments under Communist doctrines. During this period, library education has been subject to and dominated by the broader political struggles until the present. The effects of the time are dramatically manifested during the disastrous Cultural Revolution (1966-76) and, later, the golden age of China's library education of the 1980s. From 1966 to 1976, much of what had been achieved in library education was destroyed. While libraries and information centers were labeled "places full of feudalism, capitalism, and imperialism" and most of them closed, library and information personnel were called "watchdogs" and expelled to rural communities to be re-educated. Consequently, professional education in this field suffered with classes suspended, teachers dispersed to unrelated positions, and teaching materials destroyed. 4

Since the implementation of the all-encompassing "Open Door" policy, a more positive approach and active attitude towards Western civilization has been adopted. As a result, the roles and functions of library and information services changed enormously. Libraries and information centers are becoming an important part of society in improving the intellectual level 
of the whole nation, serving the economic and political reforms, and meeting the needs of the modernization drive. The application of modern technology in library and information services has challenged professional education for library and information personnel in China. These two periods, in sharp contrast to one another, clearly show that under a Communist regime like China's, the political situation has a far more tangibly decisive influence on its library education than in the Western systems, such as that of the U.S. As discussed in the subsequent sections arranged in chronological order, the historical influence of politics was by no means limited to the time of exceptional changes. 5

Reorganizing Library Education after the Founding the Communist China: 1949-1966

There were three major library schools in China in 1949: the Boone Library School at Wuhan, St. John's College Library School in Shanghai, and Beijing University Library School. All were closed in 1949 pending reorganization of the nation's higher education system. In the new climate, the training, attitudes and commitment of library workers were of immediate importance to the government. Information personnel were seen to be a critical component of the cultural, educational and propaganda apparatus of the new state. Library workers were reoriented to serve the changed objectives of Chinese society and in 1952 the Beijing University library school was reinstated along Russian lines. The Boone Library School became a department of Wuhan University in 1953. Thus after the readjustment 
following "liberation," two principal library schools emerged to cater for the nation. 6

A brief look at the library school curriculum at the University of Beijing in 1950 gives us some basic ideas about the education at the outset of the People's Republic. Apart from the standard cultural and political subjects, the following professional subjects were taught: Introduction to Library Science, Introduction to Bibliography, General Reference, Introduction to the History of Books, Chinese Bibliography, Classification and Cataloging, Textual Criticism, Filing, Indexing, History of Chinese Book Editions, Library Administration and Library Practice. ${ }^{7}$ By 1956, both the Beijing and Wuhan schools offered full-time, four-year programs in library education. 8

In addition to the two principal schools a handful of short-lived junior college level schools and special short training classes were established. An example of the former was the program offered between 1951 and 1954 at the Southwestern Normal College in Sichuan. 9 Training classes were developed along the lines of those first established in 1951 by the Cultural Department of the Northeastern Region. 10 Most provinces and cities instituted training classes to improve personnel at the county library level. Trained county library staff trained staff at lower levels, evidencing a trickle-down process. Despite this range of initiatives options for library education remained few. 11

In 1958, responding to the call of the "Great Leap Forward" and with encouragement from Mao Zedong, librarians pooled their efforts to set up library schools in what were dubbed "politically red, academically expert" colleges where experienced librarians taught part-time. 
Library Education during the

Period of Cultural Revolution: 1966-1976

The impact of the Great Proletarian Cultural Revolution on Chinese library education was devastating. Perhaps the greatest single blow to the profession relates to the fact that library educators could not practice their vocation for several years. In relation to the general field of professional development, library educators suffered through being isolated from new trends and developments in the library and information field both at home and abroad. In the absence of indigenous and foreign library and information science books and periodicals, ideas could not be disseminated. 12

Library school academics were criticized and persecuted as undesirable "stinking number nines." Librarians, dubbed "watchdogs of imperialism," were especially suspect. 13 "White expertise" was to be subsumed by "Red expertise." Universities housing library schools remained closed from mid1966 to 1971-72. Formal full-time and correspondence programs were at a standstill. ${ }^{14}$ In this climate, library knowledge rapidly lost sight of contemporary developments. Even on reopening, the "reformed" universities operated under considerable constraint. 15

The overall subjugation of theory to practice meant that the curricula of the two library schools which reopened were shortened and downgraded. Curricula were expunged of basic theoretical studies. 16 Students were selected on the basis of recommendation by local revolutionary committees. In selection, political criteria were uppermost. Only worker-peasant-soldier students were enrolled. Because of poor or inadequate foundations in 
previous educational experience, entrants were often ill-prepared for higher study and were unable to grasp course content. 17

In putting politics first and emphasizing practice, both students and faculty were selected on the basis of ideological soundness. Teachers were appointed with little theoretical or cultural knowledge. Academically qualified teachers spent between three and five years in the countryside, learning "proletarian consciousness" through manual labor. Students were selected only after having been workers, peasants or soldiers for at least three years. Academically qualified students were dubbed "good-for-nothing bookworms." There was fairly regular "Red Guard" disruption of classes and teaching routines. In fact there was no teaching at all at Beijing University or Wuhan University between 1966 and the very early 1970s. 18 Moreover, there was a decrease in student numbers because of the reluctance of students to study in a field as "useless" as librarianship. 19

Understandably, teachers lost heart and sold their textbooks, for these might incriminate them as intellectuals if ferreted out by marauding Red Guards. Teachers, demoralized, refrained from teaching; students, from learning; researchers, from researching; post-graduate study was eliminated. 20 In the decade of the "Turmoil," as it is now referred to in China, library schools were suspended, faculty members dispersed or reassigned to totally unrelated positions and teaching materials destroyed. Those actions made the recovery particularly difficult when the Cultural Revolution officially ended in $1976^{21}$. 
Open-Door Policy And

Library Education in the Post-Mao Era: 1976 to the present

The end of the Cultural Revolution in 1976 brought fresh air to all educational institutions in China. 1978 was the milestone for the recovery and development of Library and Information Science (LIS) education.

Students were soon being accepted into formal education straight from school and only on the basis of proven academic ability judged on performance in the national university entrance examinations. Previously discredited faculty were recalled and new, more qualified faculty were employed.

Undergraduate programs were reinstated. Postgraduate study re-emerged. Access to foreign ideas was provided through the collection of foreign library literature and the growth of Chinese library international relations. The latter included contact with visiting groups of foreigners, the welcoming of foreign library educators and involvement with international organizations such as United Nations Educational, Scientific and Cultural Organization (UNESCO), and International Federation of Library Associations and Institutions (IFLA). The number of formal avenues for library study began to expand as did the range of alternative, less formal options. The turning point was 1978, when important conferences were held in the fields of science and education. 22

It was in this year that Wuhan University added information science as another specialized field in its Department of Library Science, while on the other hand, Beijing University offered Library and Information Science (LIS) curricula for science students. In the same year more than ten other universities and colleges founded either a department of library science or 
specialized fields of library science and/or information science in their related departments. Among these institutions of higher learning, some were very famous, e.g. East China Normal University, Nanjing University, Nankai University and the Branch School of Fudan University. The China Society of Library Science (CSLS) was established and joined the International Federation of Library Associations and Institutions (IFLA) in 1981.23 Many students and visiting scholars were sent overseas to study librarianship and information science. Also many foreign librarians and information experts were invited to China to give lectures, seminars and other training programs. Several co-training courses, workshops and seminars were organized, which gave great opportunities for Chinese library and information professionals to learn about library and information services in foreign countries. As a result, international exchange and cooperation were improved in many fields. All the phenomena discussed above were signs that China's LIS education had come into a new period of development. 24

Since 1978, library and information science education has developed rapidly in China. The number of library schools increased from two in 1978 to 47 in 1985, and to nearly 70 in the late 1980s. 25 But in comparison with the increasing need for information in a large country with a population of about 1.2 billion, there is still a long way to go. Demand for well-trained and qualified librarians and information specialists is immense. A consequence of this lack of emphasis on library education was that many libraries were seriously lacking well-trained personnel; only 2.5 percent of staff working in libraries and information centers had been professionally trained. 26 A major complaint from library patrons was difficulty in obtaining appropriate 
documents. The chief reason for this could be the poor services provided by unqualified librarians. It is disturbing that a country that prides itself on its literary heritage reached such a situation.

An official recognition of the need for qualified personnel is the motivating force in the development of library and information science education. Looking back over its historical development, three periods with good support for library education can be distinguished in China: (1) the early period in the 1920s, (2) the development period from the 1950 s to the mid1960s, and (3) the "Golden Age" of the 1980s. The emergence of the three periods was not an accident. During the 1920s, libraries in China were confronted with the situation of the new replacing the old in response to the influence of Western countries. Library education emerged as the time required. During the period from the 1950 s to the mid-1960s, the government called for promoting industrialization and a "March Towards Science." One consequence was that libraries and library education expanded dramatically. In the 1980s, a policy of reform and opening up to the outside world brought vast changes to library and information science education. 27

Since 1978, great progress has been made in China's library and information services. This has caused an urgent demand for a large number of personnel qualified in library and information science. For this reason, great importance is now widely attached to professional education. Several meetings have already been held by the China Society of Library Science and the Society of Information Science to discuss professional education, and two special conferences were convened by the former ministry of Education in 1981 and 1983 to deliberate on the above subjects. The former Ministry of 
Education made a preliminary estimate of the need for qualified personnel in the period from 1983 to 1990 at the symposium held in 1983 and came to the conclusion that education in library and information science must be greatly developed and conscientious reforms must be carried out. 28

China's approach is uniquely its own because it neither simply imitated the Western educational systems in the early 20th century, nor did it copy indiscriminately those of the Soviet Union in the 1950s. China has sifted through and gradually integrated what it found valuable from the many and various educational systems of the world, evolving a system with its very own Chinese characteristics. 29

Raising the educational level of the entire Chinese people for realizing the "four modernizations" is an ambitious program to modernize agriculture, industry, national defense and science and technology by the end of this century. In this grand endeavor, library development and the role of libraries as a distinct and vital force in the modernization process of the century are once again recognized. Some prominent facts and features of the development of LIS education in early 1980's are:30

- A unique and effective education system in library and information science. After decades of preparation, an effective education system of LIS with its own Chinese characteristics has been founded. Such a system can be classified into three categories. They are higher education, secondary education and continuing education.

-- Secondary Education. Different work in library and information centers needs different types of personnel, so secondary education to train skilled assistants to professional librarians in academic, school, public and 
special (e.g. company, government and medical) libraries is one of the crucial aspects of the LIS education. Because no secondary library school was available for decades, much attention has been paid to secondary education by the provincial library and information centers around the country since the beginning of the 1980's. After dozens of secondary level training programs were offered in some provincial libraries, the first secondary school--Hunan School of Library and Information Science was formally set up in 1984. 31 Although nine secondary schools have reportedly emerged around the country, they are far from enough to supply professionally trained junior library staff to meet the challenge of the information age.

-- Higher Education. Most schools of LIS were established in comprehensive universities or large normal universities where many curricula of other disciplines can be absorbed. Students in these schools were mainly chosen from academic senior middle schools by the highly competitive college entrance examination. Most of them had no library experience beforehand. The recent development in LIS education, can be exemplified by the progress achieved in Wuhan University and Beijing University. In 1981, both universities were admitted by the Ministry of Education to be the first two universities which could give the master of arts degree in librarianship to their postgraduate students in fields of foundations of library science, bibliography, library classification, theory of information science and reference materials written in foreign languages. 32 The Department in Beijing University now has two divisions, one specialized in humanities and social sciences and the other in science and technology. The Department in Wuhan University was expanded to the College of LIS in 1984 
with four specialized fields: library science, information science, archives management and book publishing and dissemination. 33 The College of Library and Information Science, together with its subsidiary Institution of Library and Information Science, is playing an important role in training qualified professionals and teaching staff of other departments of LIS; therefore, it is gradually becoming the national center of LIS education.

-- Continuing Education. In 1980, there were 143,000 staff working in libraries/information centers, only two percent of whom were professionally trained and qualified. In academic and special libraries and information centers, only five percent of the staff were professionally trained. 34 Obviously, library and information personnel are unable to keep up with the rapid advances in technological equipment in library and information centers. As a result of the information explosion and the rapid changes in knowledge, on-the-job continuing education programs are badly needed. The continuing education program is described below. 35

- Professional training in library science. This is designed mainly for newcomers who do not major in library science. During the training, there are short-term training courses for them, and they are sent to visit suitable libraries or, sometimes, to do practice work in different professional departments. Each course lasts 2-3 months. This method works well. The short term training courses help laymen to acquire the rudimentary knowledge and practical ability for their work. A series of teaching materials have been edited and compiled. They are Introduction to Library and Information Science, Acquisition of Library Materials, Serials Control, Classification, Cataloguing of Chinese and Japanese Materials, Cataloguing of 
Foreign Languages Materials (including English, French, and German etc.), Cataloguing of Russian Language Materials, Readers Service, Reference Service and Information Retrieval, The Use of Scientific and Technological Reference Books, Copyright and Reproduction of Materials, Information Analysis, The Application of the Computer to Library and Information Service--13 titles in all. 36

- Foreign language training classes. Foreign languages are of great importance to the professional staff. They are especially necessary because of the institution of an open policy with the outside world. In addition, some units send their librarians directly to language schools or colleges to improve their reading, translating, and speaking ability to deal with scientific and technological materials and to lay the foundation for visiting or studying abroad. This improves the quality of acquisition, cataloguing, analysis, and provision of scientific and technological information in foreign languages. 37

- Training through Seminars. The purpose is to provide certain senior librarians with an opportunity to improve their professional ability. The seminars are organized with a combination of lectures, discussion, investigation, and contribution of articles.

--Professional lectures on natural science. In order to keep abreast of the rapid developments in science and technology, well-known experts are invited to give lectures on general concepts, classification, the content and history of various special techniques so that the people in those units can more easily serve users in a timely and direct way.

- New technology training class. With the rapid development of science and technology, great changes have taken place in the field of library 
technology. Computers have brought a revolution in library technology. The applications of photography, microfilms, video technology and computers to library systems have not only made the work more efficient but also developed new fields and working methods. Therefore, librarians working in modern libraries should not only become familiar with the new technology but also master it for their routine business. At present, 30 percent of the staff in county, middle school, and small libraries and 50 percent of the staff in provincial, academic, and special libraries and information centers have been professionally educated. The rapid improvement in the quality of personnel is not only the result of formal education, but also due to continuing education or on-the-job education. 38

Correspondence courses, mainly self-directed learning with regular on site visits by trainers and consultants have turned out to be one of the most important kinds of continuing education. The departments of LIS in Wuhan University, Beijing University and East China Normal University are offering correspondence programs in more than 40 major cities throughout the country with the help of local library societies. As of 1988, 3,019 correspondence students have graduated while another 2,551 students have been registered in various correspondence schools of LIS.39

Correspondence study solves geographical problems and, consequently, supplies equal opportunities for those unable to attend formal education, such as disabled and middle-aged men or women with families. Some experts predict that, with the advent of some new technologies, the availability of resources in the continuing education centers could be greatly enhanced by means of satellite conferences in which programs could be 
beamed to distant locations. These could be transmitted by one-way video, two-way audio panel discussions in which experts could discuss a subject and have direct interaction by means of questions from the participants in other locations. 40

-- The Reform of the Curriculum. Applications of modern technology in Chinese libraries and information centers, together with the increasing demand for human recorded knowledge, have both tested the educational preparation of library and information personnel and created new educational demands. The previous curricula in library and information science faculties have to be reviewed and expanded.

Two approaches have been taken by library and information science educators in China to reform their curricula. 41 First many library and information science faculties incorporate information science courses into their traditional curricula. For instance, the foundation course tends to cover both library and information science. As a supplement, a number of courses of information science such as information storage and retrieval, management of scientific literature, basic principles of computing programming, files and database management, data structure and audiovisual material management have been introduced into the curriculum of library and information science schools.

Secondly, some schools divide their students into more specific subject groups according to their future responsibilities. Students of humanities or social sciences are encouraged to specialize in the research and services of Chinese rare books or social sciences/humanities literature, while students of science dwell on science and technology communication and the 
management of scientific literature. In addition, more elective subjects are offered by library and information science schools so that students can get a better idea of what kind of work they'll be doing in the future. A few schools place their professional education programs in more specific areas. For example, the Jilin Medical College in Jilin Province emphasizes medical information services, and Nanjing Agriculture University, agricultural information services.

Since there is no authoritative organization responsible for the quality of these programs and co-ordination among different schools, common understanding and agreement on requirements for core and elective elements for the educational preparation of potential librarians and information specialists are desirable. A national symposium was held in 1985 by the China Society of Library Science to discuss the curriculum in professional education for library and information personnel. Most delegates agreed that college education programs for training library and information professionals should include at least the following ten courses: 42

\section{Introduction to LIS}

This course is intended to give students a general idea of the functions and aims of various kinds of libraries and information centers and the role they play in the process of the modernization. The nature of librarianship, fundamental theories of LIS as well as the description of library materials, arrangement of materials, communication of knowledge and library network are also discussed. 
2. Classification and Subject Headings.

Classification and subject headings are used for arrangement of library materials. Standard classification schemes e.g. CLC (China Library Classification), as well as some subject headings like the Chinese Thesaurus and the Library of Congress Subject Headings (LCSH). In addition, collection development, utilization of material sources and user services are also included.

3. Cataloguing in Both Chinese and Foreign Languages.

Introduction to book cataloguing is based on the Cataloguing Standard of Chinese Books and the Anglo-American Cataloguing Rules, second edition. Principles of main entry, authority files, descriptive cataloguing, and bibliographic sources for cataloguing are included.

4. Bibliography.

Much emphasis is placed on modern bibliography, especially the management of secondary literature, the compilation of digests and indexes in many specific fields.

5. Reference Materials and Services.

This course provides an introduction to reference work and the effective use of books, catalogues, and other materials as sources of information. Students are instructed in the use of basic reference books and in techniques of reference services.

6. Information Storage and Retrieval.

This course includes functions and principles of information retrieval in library and information centers, and the use of some printed materials. 
7. Management of Library and Information Services.

This course includes library system analysis, administrative structures and relationships in library and information centers, work study and job classification in library networks, and the evaluation of library performance. 8. Collection Development and User Services.

This course includes study of the characteristics of materials, both in printed form and non-print form, stack management, systematic analysis of the library process from check in to shelflist, materials weeding and resource sharing.

9. Library Automation.

This includes introduction to computerized circulation control systems, automated cataloguing, automated reference service and automated acquisition and serials control, as well as knowledge of the computer itself such as computer hardware, software, data processing concepts and automated office systems.

10. Computerized Information Retrieval Systems.

This course includes the development of computerized information retrieval systems in other parts of the world, introduction to some effective on-line retrieval networks like OCLC, WLN, DIALOG, MEDLINE, and other electronic retrieval systems. Students are encouraged to design computer programs in their own laboratory.

Students complete these ten courses in the professional programs in every department of library and information science in China, although the names of the courses may differ among various institutions. The depth of content also varies according to different levels. In departments of 
information science, courses such as mathematics, statistics, and computer science are added.

Generally speaking, in the two universities, there are the undergraduate and graduate programs in library and information science. The undergraduate program is the principal one. It is intended for the training of library staff for larger libraries. The graduate program is intended to train library science educators and researchers. These programs have two divisions: (1) humanities and social sciences; and (2) science and technology. There are curricula in a few library schools that have their own areas of emphasis. For instance, the Information Engineering Department of Jilin Industrial University offers a number of mechanical and electrical special courses and stresses knowledge of related scientific theories. Students are cultivated for "all-round" information expertise in the machine manufacturing industry. Most courses in library schools, however, have much in common. 43

The specialized courses for library science at Wuhan University and Zhongshan (Sun Yatsen) University are as follows: 44

(1) Introduction to Library and Information Science,

(2) Classification and Subject Headings,

(3) Cataloguing books in Both Chinese and Western languages,

(4) Bibliography,

(5) Reference Services,

(6) Information Storage and Retrieval,

(7) Automation of Libraries,

(8) Non-book Materials, 
(9) Management of Library Services,

(10) Collection Development,

(11) User Studies,

(12) History of Chinese Books,

(i3) History of Libraries in China,

(14) Rare Editions and Ancient Books,

(15) Library Architecture,

(16) Typing Skill,

(17) The Application of Computers in Libraries,

(18) Patent Knowledge,

(19) Periodical Management,

(20 Comparative Librarianship,

(21) Literature of Social Sciences,

(22) Literature of Science and Technology,

(23) Practicum.

The courses in information science curriculum at both universities include:

(1) Introduction to Information Science,

(2) Information Retrieval,

(3) Sci-tech Document Management,

(4) Analysis and Studies of Scientific Information,

(5) Components and Structure of Computers,

(6) Data Structures,

(7) Computer Networks,

(8) Information Retrieval Languages, 
(9) Information Retrieval Systems,

(11) Programming Languages,

(12) Operating Systems,

(13) Message Processing for Chinese Characters,

(14) Formal Languages and Automation,

(15) Compiler and Translator Methods,

(16) Pattern Recognition,

(17) Economics of Information,

(18) Practicum.

The above courses are the undergraduate courses. The courses of the graduate programs vary greatly in different fields of study such as library management, local collections, theoretical studies of librarianship, and the history of libraries in China.

In discussing China's library education, one should always keep in mind that China is, in the final analysis, a socialist country, and the libraries continue to be operated under the rule and regulations of the central Communist government. Meanwhile, library education has never shifted away from its subordinating function in carrying out the Communist Party's educational policies and preparing young librarians with an education that is still Marxist or Communist in some fundamental ways. These fundamental ways can include a whole syndrome of rules and principles. Nevertheless, they can be encapsulated in the alleged "Four Basic Principles," which have been extolled by the Chinese ideologues as the "Four Pillars" of socialist revolution and construction. They require a long-run insistence on Marxist- 
Leninist-Maoist doctrines, socialist orientation, Communist leadership, and proletariat dictatorship. 
Notes

1Weiming Li, "Professional Education for Library and Information Personnel in China," International Library Review 21(2) (April 1989): 263-275.

2 Chao-hua Xie, ed., Zhonggue Tushu He Tushuguanshi (History of Chinese books and libraries) (Wuchang: Wuhan University, 1987), 7.

3S. C. Lin, "Historical Development of Library Education in China," Lournal of Library History 20(4) (Fall 1985): 368-386.

4Lee-hsia Hsu Ting, "Library Services in the People's Republic of China: A Historical Overview," The Library Quarterly 53:2 (April 1983) :134160.

${ }^{5}$ Ziming Liu," "A Comparative Study of Library and Information Science Education : China and the United States," International Information \& library Review 24:2 (June 1992): 107-118.

${ }^{6} \mathrm{John}$ Barclay, The Seventy-Year Ebb and Flow of Chinese Library and Information Services: May 4,1919 to the late 1980s (Metuchen: The Scarecrow Press, Inc., 1995), 29.

7S. C. Lin, "Historical Development of Library Education in China," Journal of Library History 20(4) (Fall 1985): 368-386.

8Y.H. Quan, "Continuing Education of Library Science in the New China," [unpublished paper, 1984] ERIC Document 269020.

${ }^{9}$ S. C. Lin, "Historical Development of Library Education in China," Journal of Library History 20(4) (Fall 1985): 368-386.

${ }^{10}$ S. C. Lin, "Historical Development of Library Education in China," Lournal of Library History 20(4) (Fall 1985): 368-386.

${ }^{11}$ John Barclay, The Seventy-Year Ebb and Flow of Chinese Library and Information Services: May 4, 1919 to the late 1980s (Metuchen: The Scarecrow Press, Inc., 1995), 30.

12John Barclay, The Seventy-Year Ebb and Flow of Chinese Library and Information Services: May 4, 1919 to the late 1980s (Metuchen: The Scarecrow Press, Inc., 1995), 103. 
${ }^{13}$ Weiming. $\mathrm{Li}$, "Meeting the Challenge of the High Tech Information Age-the Recent Development of Library and Information Science Education in the People's Republic of China," paper presented at the 52nd IFLA General Conference in Tokyo, 1986. 1-12.

${ }^{14} \mathrm{~T}$. Zhu, "Thirty Years of Correspondence Education in Library Science in China," Education and Research in Library and Information Science in the Information Age 6 (1988): 167-172.

15John Barclay, The Seventy-Year Ebb and Flow of Chinese Library and Information Services: May 4, 1919 to the late 1980s (Metuchen: The Scarecrow Press, Inc., 1995), 103.

16K.P. Broadbent, Dissemination of Scientific Information in the "People's Republic of China (Ottawa: International Development Research Centre, 1980), 19.

17Kent, A. and Lancour H., eds. Encyclopedia of Library and Information Science (New York: Marcel Dekker, 1970), s.v. "China, Libraries in the People's Republic of China of," by K. T. Wu.

18Y.H. Quan, "Continuing Education of Library Science in the New China," [unpublished paper, 1984] ERIC Document 269020.

${ }^{19}$ Lee-hsia Hsu Ting, "Library Services in the People's Republic of China: A Historical Overview," The Library Quarterly 53:2 (April 1983) :134160.

20John Barclay, "The Four Modernizations Embrace Libraries in the People's Republic of China," Australian Library Iournal 28(7) (May 1979): 102110.

21S. C. Lin, "Education for Librarianship in China after the Cultural Revolution," Iournal of Education for Librarianship 24(1) (Summer 1983): 1730.

22John Barclay, The Seventy-Year Ebb and Flow of Chinese Library and Information Services: May 4, 1919 to the late 1980s (Metuchen: The Scarecrow Press, Inc., 1995), 170. 
23Zongzhong Huang, "Tushuganxue Rumen" (Introduction to Library Science) (Wuhan: Wuhan University Press, 1984) 602.

24Sun Yang, "Library Education in 2000," in Research Materials in Chinese Librarianship (in Chinese) (Beijing: China Society of Library Science, 1984),18-25.

25Ziming Liu, "A Comparative Study of Library and Information Science Education: China and the United States," International Information and Library Review 24 (1992): 107-118.

26Weiming Li, "Professional Education for Library and Information Personnel in China," International Library Review 21(2) (April 1987): 263-275.

27Ziming Liu, "A Comparative Study of Library and Information Science Education : China and the United States," International Information \& library Review 24:2 (June 1992): 107-118.

28 Ming Cheng, "China Society of Library Science," Zhongguo Tushuguan Xuehui Chenglidahui Zhuanii (The Founding of the China Society of Library Science) (Beijing: Commerce Press, 1979): 23-26.

${ }^{29}$ Ziming Liu, "A Comparative Study of Library and Information Science Education : China and the United States," International Information \& library Review 24:2 (June 1992): 107-118.

${ }^{30}$ Weiming $\mathrm{Li}$, "Meeting the Challenge of the High Tech Information Age-the Recent Development of Library and Information Science Education in the People's Republic of China," paper presented at the 52nd IFLA General Conference in Tokyo, 1986. 1-12.

31The Science and Technology Association of China, "Zhonggue Dushugan Jiaoyu de Fazhan Yu Xianzhuang" (The Development and Present Situation of Library Education in China) (Beijing: Chinese Library Association, 1984), 25.

32Yanli Qi, "Library and Information Science Education in China," International Library Education 36:2 (Spring 1995): 180-183. 
33Wuhan University, "Wuhan Daxue Tushuxinxi Xi ," (The College of LIS Established in Wuhan University) (Wuhan: Wuhan University Press, 1984), 4.

34Yanli Qi, "Library and Information Science Education in China," International Library Education 36(2) (Spring 1995): 180-183.

35Weiming $\mathrm{Li}$, "Meeting the Challenge of the High Tech Information Age-the Recent Development of Library and Information Science Education in the People's Republic of China," paper presented at the 52nd IFLA General Conference in Tokyo, 1986. 1-12.

36Weiming Li, "Meeting the Challenge of the High Tech Information Age-the Recent Development of Library and Information Science Education in the People's Republic of China," paper presented at the 52nd IFLA General Conference in Tokyo, 1986. 1-12.

37 Kent, Allen, and others, eds. Encyclopedia of Library and Information Science (New York: Marcel Dekker, 1977), s.v. "Library and Information Science Education in the People's Republic of China," by Yimin Yan.

38Yanli Qi, "Library and Information Science Education in China," International Library Education 36(2) (Spring 1995): 180-183.

${ }^{39} \mathrm{~T}$. Zhu, "Thirty Years of Correspondence Education in Library Science in China," Education and Research in Library and Information Science in the Information Age 6 (1988): 167-172.

40IFLA General Conference, Education and Research Division, Library School and Other Training Aspects (52nd, Tokyo: International Federation of Library Associations (IFLA), 1986), 24-30.

41.Weiming $\mathrm{Li}$, "Computer Information Systems in the People's Republic of China, Current Advances and Prospects to 1995," Library and Information Science Education 6 (1986): 1-11.

42Weiming Li, "Professional Education for Library and Information Personnel in China," International Library Review 21(2) (April 1989): 263-275. 
${ }^{43}$ Kent, Allen, and others, eds. Encyclopedia of Library and Information Science (New York: Marcel Dekker, .1977), s.v. "Library and Information Science Education in the People's Republic of China," by Yimin Yan.

44 Dongfa Xiao, "Forty Years of Library and Information Education in New China, 1949-1989," Tushuguanxue Tongxun (Librarianship Bulletin) 1 (1988): 3-10. 


\section{Chapter IV}

\section{SUMMARY AND CONCLUSIONS}

Since the Chinese Communists took over the mainland in 1949, they have made all-out efforts toward the development of libraries and extension of library facilities. During the past forty years, library development has followed a tortuous road. Even though it has been up and down, generally speaking, there has been more development of libraries after 1949 than during previous historical periods.

Having said that, we also have to acknowledge that the Chinese Communists efficiently and fatally constrained the new library system within a very narrow set of goals and objectives as soon as they gained power. As a matter of fact, as with other parts of the social structure, libraries became a tool of politics. In that sense, while the expansion that the system underwent might be said as unprecedented, its confinement in terms of the political or intellectual freedom was also unprecedented. The same can be stated for the library education. This evaluation of the historical role of the library system during the time of Mao can be powerfully summarized by an ideological phrase catchword that is actually a well-known quotation of Mao, "everything should serve the proletariat politics."

From the 1970's onwards, China's reform has lasted nearly two decades, surging from the countryside to the city, from the economic system to political and social systems, and from revitalizing the domestic economy to opening to the outside world. China has determined its goals in developing 
its economy. In the last dozen years, the economy has been vigorous, has developed in a sound base and has attracted much interest at home and abroad.

Through the reform and opening to the outside world, a more positive approach and active attitude towards Western civilization has been adopted. All these have changed the roles and functions of library and information services enormously. Libraries and information centers are becoming important parts of society in improving the intellectual level of the whole nation, serving the economic and political reforms, and meeting the needs of the modernization drive.

Deng Xiaoping's modernization reform and the application of modern technology in library and information service has created great challenges for professional education of library information personnel in China. Demands for well-trained and qualified librarians and information specialists are immense and in response to this need, library education programs have greatly expanded in the last decade.

The societal need for information is one motivation for library education. In China, under the closed-door policy and centralized economic planning, there was less demand for information, librarians and information specialists. Therefore, the progress of library education in China moved very slowly until the 1980 s. Libraries are always impacted by the current economic situation. Economic development not only calls for corresponding information services, but also provides favorable conditions for the development of libraries. On the other hand, the development of libraries is also beneficial for accelerating economic growth. 1 After 1978, the focus of 
Chinese government policies shifted from political ideology to economic construction, from centralized economic planning to a market-oriented planning approach. The shift of emphases and rapid economic growth made the lack of libraries and librarians a more serious concern. Undoubtedly, all these changes stimulated the progress of library education as well as the expansion of libraries in China.

That rapid transformation raises a fundamental question about the library system and library education under a social system which is still Communist. Have the political control and censorship decreased? If so, does that suggest they will diminish and disappear in the long run? Viewing the question in historical perspective, we have to recognize that, with all the twists and turns, on the whole the library system in China has experienced a decrease of Party control and supervision. The shock waves of the information age have broken the paranoid obsession with what should be written. Political legitimation depends more and more on people's prosperity rather than political ideology.

We have also to recognize that the political subordination of libraries to the central authority continues. In appearance, and in historical comparison, it may well seem to have weakened a great deal. But politics are still in command, and certain deeply entrenched boundaries have not been crossed. Expression of the authentic opposition or voice of dissidents are nowhere to be found in the library. No skepticism about the current regime or its policies is supposed to be vented or printed. The political authority has never ceased to cleanse from the growing number of publications the 
elements they define as " counter-revolutionary," "reactionary," and reflecting an "unhealthy or decadent life style," and confiscate the books when deemed necessary.

Following the Open-Door Policy, the shock waves of the new information age have shaken up the outmoded way of thinking. However, some deep structure of the Communist body politic remains. It is true that the gravity of legitimation for the regime has somewhat shifted from political ideology to economic prosperity. And yet, no one claims to have abandoned the Marxist principle of dictatorship. As the lifeline, it has never been abandoned in actuality. As a matter of fact, just the opposite is true. The police force and army have been greatly enhanced to guarantee the security of the regime. The hardliners have had their political ups and downs but they have never failed to be politically vigilant. So long as the political color of China does not change, the censorship and tight political control cannot dissolve by themselves.

In final summary, the development of Chinese libraries has been conditioned by the political and economic conditions of the country. The Communist Party has dominated every aspect of library operations. The role and policies of libraries have thus been changed several times in accordance with shifting Party lines. But the unchanging political mandate of the library and librarians is discernible throughout history and even today. Bearing that in mind, and with all the future unpredictability, we can still harbor the hope that the new generation of librarians will be permitted a larger share in library management (even policy-making) and be allowed to exercise their professional judgment in achieving the goal of dissemination of knowledge. 


\section{Notes}

1Ziming Liu, "Zhongguo Tushuguanliyuan Peiyang Xingshi," (On the Patterns of Development of Librarianship in China) Lournal of the Graduates of Zhongshan University no. 2 (1989): 94-96. 
WORKS CITED

Academic American Encyclopedia, 1993 ed. S.v. "Agriculture."

Bahr, Lauren S., and Bernard Johnston, eds. Collier's Encyclopedia: with Bibliography and Index. New York: P.F. Collier, 1993. S.v. "National Government," by Thomas R. Tregear and Shane Mage.

Barclay, John. The Seventy-Year Ebb and Flow of Chinese Library and Information Services: May 4, 1919 to the late 1980s. Metuchen: The Scarecrow Press, Inc., 1995.

Borthwick, Mark. Pacific Century: The Emergence of Modern Pacific Asia. Boulder: Westview Press, 1992.

Broadbent, K.P. Dissemination of Scientific Information in the "People's Republic of China. Ottawa: International Development Research Centre, 1980.

Chandler, George. "The Chinese Library System." International Library Review 12(4) (October 1980): 393-427.

Chao, Yule Zhongguo Chaodai Yanjiu. (Studies of the Chinese dynasties) Beijing: Commence Publishing House, 1978.

Cheng, Chi. "Libraries in China Today." Libri 9(2) (1959): 105-110.

Cheng, Chu-yuan. The Economy of Communist China, 1949-1969. Ann Arbor: University of Michigan, Center for Chinese Studies, 1971.

Cheng, Ming. "China Society of Library Science." Zhonggue Tushuguan Xuehui Chenglidahui Zhuanji (The Founding of the China Society of Library Science). Beijing: Commerce Press, 1979: 23-26.

Chiang, Fu-tsung. "A Historical Sketch of Chinese Libraries." Philobiblon 2 (2): 1-6 (March 1978): 21-26.

Chien, Fu-chi. "1964 Nian de Guangrong Renwu, Touru Shin de Zhandou Shelun." (Editorial: the glorious task of 1964: start a new struggle) Tushuguan (Libraries) 1 (March, 1964): 1. 
"Children's 'Books from the New China." In Racism and Sexism in Children's Books. 101-106. London: Writer's and Reader's Publishing Cooperative, 1979.

China Handbook Series--Culture. Compiled by the China Handbook Editorial Committee. Beijing: Foreign Languages Press, 1982.

China (1949-1958) State Statistical Bureau, comp. Ten Great Years. Beijing: Foreign Language Press, 1960.

"Chinese Communist Library Service in the Past Decade." Union Research Service 19(8 and 10) (April and May 1960): 106-115+131-149.

Chun, Hung. "Dui Xian Tushuguan Gongzuo Zhong de Wenti de Yijian." (Opinions on the issues concerning the county libraries) Tushuguan Gongzuo (The library Work) 12 (December 1957): 32.

Clubb, O. E. "China after Mao." Current History 73 (429) (September 1977): 4953 and 86.

Cui, Y. "Zhongguo de Tushuguan Gongzuo." (Communist Chinese Library Work) Ziguo Zhoukan (Ziguo Journal) no. 6 (November 1961): 12-15.

Dahl, Steven. History of the Book. New York: Scarecrow Press, 1958.

Delany, Brian, and Lynn W. Paine. "Shifting Patterns of Authority in Chinese Schools." Comparative Education Review 35 (1) (February 1991): 23-43.

$\mathrm{Du}, \mathrm{Ke}$. "A Preliminary Probe into Establishing a Network of Libraries in Our Country." (in Chinese). Tushuguanxue Tongxun (Bulletin of the Library Science) no. 1 (June 1979): 22-26.

Elegant, Robert S. Mao's Great Revolution. New York: World Publishing Co., 1971.

Encyclopedia Americana, 1992 ed. S.v. "Ethnic and Linguistic Groups."

Encyclopedia of Library and Information Science, 1968 ed. S.v. "Library Development in Communist China."

Encyclopedia of Library and Information Science, 1978 ed. S.v. "Public Libraries, Fast East, People's Republic of China." 
Fraser, Stewart E. Education and Communism in China. London: Pall Mall Press, 1971.

Fu, Zhenghong. "Jianchi Shehui Zhuyi Banxue Fangxiang de Jidian Wenti" (Several Issues Concerning the Orientation of Running Socialist Schools). ذiaoyu Yanjiu (Educational Research) 1 (January 1990): 13-16.

Giblin, J. C. "A green Heart: Notes on Children's Cultural Activities." The Horn Book Magazine 51(6) (December 1975): 564-570.

Guangming_Ribao (Enlightenment Daily) (Beijing), 15 May 1981.

Hsia, T.T., and K Haun. "Communist Chinese Legislation on Publications and Libraries." Quarterly Journal of the Library of Congress 27(1) (January 1970): 20-23.

Hu, Y. "China's Four Modernizations and Library Service." Paper presented at the IFLA General Conference, 1983, 5.

Huang, Zongzhong. "Education in Librarianship: Retrospect and Prospects," (in Chinese). Tushuguanxue Tongxun (The Bulletin of Library Science) no. 5 (September 1980): 16-25.

. "Libraries in New China during the Past Three Decades." (in Chinese) Wuhan Daxue Xuebao: Zhexue Shehuikexue Ban (Bulletin of Wuhan University: Philosophy and Social Sciences) 2 (1979): 228-45.

IFLA General Conference, Education and Research Division. Library School and Other Training Aspects. 52nd, Tokyo: International Federation of Library Associations (IFLA), 1986.

Kelly, D. A. "At Last, an Arena: Current policies in Chinese Social Science." The Australian Joumal of Chinese Affairs no. 2 (July 1979): 123-136.

Kent, Allen, and others, eds. Encyclopedia of Library and Information Science. New York: Marcel Dekker, 1977. S.v. "The History of Libraries in China," by W.S. Wong.

Kirkes, S. "Mao as Library User and Worker: How Early Experiences in Traditional Chinese Libraries Contributed to Mao's Revolutionary ideas." American Libraries 7(10) (November 1976): 628-631.

Krasilovsky, P. "What Chinese Children Read." Publishers Weekly 203 (9) (February 1973): 100-101. 
Kung, Jen-min. "Shi Tushuguan." (Municipal Libraries) Wuhan Daxue Renwen Xuebao (Journal of humanities of the Wuhan University) no.3 (1969): 2.

Kuo, Leslie T. C. "Communist China: Restoration and Expansion." Library Lournal 87(20) (November 15, 1962): 4133-4136.

$\mathrm{Li}$, Weiming. "Computer Information Systems in the People's Republic of China, Current Advances and Prospects to 1995." Library and Information Science Education 6 (1986): 1-11.

. "Meeting the Challenge of the High Tech Information Age-the Recent Development of Library and Information Science Education in the People's Republic of China." Paper presented at the 52nd IFLA General Conference in Tokyo, 1986. 1-12.

-..-.-. "Professional Education for Library and Information Personnel in China." International Library Review 21(2) (April 1989): 263-275.

Lin, S. C. "Education for Librarianship in China after the Cultural Revolution." Lournal of Education for Librarianship 24(1) (Summer 1983): $17-30$.

- "Historical Development of Library Education in China." Lournal of Library History 20(4) (Fall 1985): 368-386.

Liu, Guojun. "Libraries in New China: a Survey of the Past Ten Years." (in Chinese) Beijing Daxue Xuebao (Bulletin of Beijing University) no. 18 (October 1959): 93-107.

Liu, Shaoqi. "Qingzhu Sulian Shiyue Shehuizhuyi Geming Sishi-zhounian Shengde Jianghua." (Speech at the Meeting Celebrating the Fortieth Anniversary of the Russian October Revolution of Socialism) Renmin Ribao (People's Daily) 7 November 1957.

Liu, Ziming. "A Comparative Study of Library and Information Science Education: China and the United States." International Information and Library Review 24 (1992): 107-118.

-.-. "Education for Librarianship in China after the Cultural Revolution." Ioumal of Education on Librarianship 16 (1983): 19.

-.-. "Zhonggue Tushuguanliyuan Peiyang Xingshi." (On the Patterns of Development of Librarianship in China) Journal of the Graduates of Zhongshan University no. 2 (1989): 94-96. 
Lu, Cheng-ching, ed. Tushuguan Xue Cidian. (The Dictionary of Library Science) Beijing: Commerce Press, 1958.

---.-.. "Tushuguan Shiyeshi." (The History of Libraries) Tushuguanxue Tongxun (Bulletin of the Library Science) 2 (My 1963):37.

Luo, X. "Management Development and its Practice in Chinese Library and Information Services." International Library Review 17(2) (April 1985): 129-149.

Ma, J. T. "Libraries in the People's Republic of China since 1949." Wilson Library Bulletin 45(10) (June 1971): 970-975.

McDannald, Alexander Hopkins, and others, eds. The Americana Annual: an Encyclopedia of the Events. New York: Americana Corporation, 1994. S.v. "China. Information Highlights," by John Bryan Starr.

Meisner, Maurice J. Mao Zedong de Zhongyuo. (Mao's China and After) Beijing: Shehui Kexue Wenxue Chubanshu, 1992.

"National Library Work Conference Concludes." Translated in Survey of China Mainland Press No. 1745 (April 1958): 16-17.

Nee, V. "The Political and Social Bases of China's Four Modernizations." Columbia Iournal of World Business 14 (2) (Summer 1979): 23-32.

Nelson, D. M., and R.B. Nelson. "The Red Chamber." Lournal of Library History 14(2) (Spring 1979): 121-128.

Ng, A W-T. "Library Development in the People's Republic of China, 19491960." Thesis F.L.A., London: The Library Association, 1976.

Peng, T. C. "New China's Libraries." China Reconstructs 5 (SeptemberOctober 1952): 44-48.

Proett, Polly-Ann Brumley. "A History of Libraries in the People's Republic of China." Ph.D. diss., George Washington University, 1974.

"The Public Library Undertaking Prospers Day by Day" Guangming Ribao (Enlightenment Daily) (Beijing), 15 May 1989.

Pulleyblank, Edwin G. "Records of the Grand Historian: Qin Dynasty." Pacific Affairs v.66:4 (Winter 1993): 625B. 
Qi, Yanli. "Library and Information Science Education in China." International Library Education 36(2) (Spring 1995): 180-183.

Quan, Y.H. "Continuing Education of Library Science in the New China." [unpublished paper, 1984] ERIC Document 269020.

Rayne, R. Mao Zedong, Ruler of Red China. New York: Schuman, 1950.

Reith, David. "The Library as a Social Agency." In The Library in Society ed. Robert A. Rogers and Kathryn McChesney , 5-16. Littleton, Colorado: Libraries Unlimited, 1984.

Science and Technology Association of China. "Zhongguo Dushugan Jiaoyu de Fazhan yu Xianzhuang." (The Development and Present Situation of Library Education in China). Beijing: Chinese Library Association, 1984.

Stones, R. "An Introduction to Children's Books in the People's Republic of China." Bookbire 15 (1) (1977): 8-18.

Ting, Lee-hsia Hsu. "Chinese Libraries and Library Education, 1949-1980: Truth and Myth in the People's Republic of China." Paper presented at the 100th annual conference of the American Library Association, 29 June 1981, 1-28, EDRS, ED 214516, microfiche.

--... "Library Services in the People's Republic of China: a Historical Overview." Library Quarterly 53(2) (April 1983): 134-160.

Walder, Andrew. "Social Change in Post-Revolution China." Annual Review of Sociology 15 (1989): 405-25.

Wang, Chang-pin. "Tantan Sheng Tushuguan Wei Nungye Fuwu de Gongzuo." (A discussion of the Service of the Libraries for the Agriculture) Tushuguan (Libraries) 3 (September 1963) 4.

Wang, Julia. A Study of the Criteria for Book Selection in Communist China's Public Libraries. Hong Kong: Union Research Institute, 1968.

Wang, L. L. "The Library on the Chinese Mainland." Issues and Studies 13(1) (January 1977): 91-106.

Wang, Shu-chi. "Gonggong Tushuguan Gongzuo." (the Work of Public Libraries) Tushuguan Gongzue (The Library Work)3 (March 1957): 40. 
Wang, Youmei. "Thirty Years of Library Development in the People's Republic of China." International Library Review 14 (May 1982): 399409.

Whitson, W.W. "China's Quest for Technology." Problems of Communism 12(4) (July-August 1973): 16-29.

"Woguo Shinianlai de Tushuguan Shiye." (Libraries in China During the Past Ten Years) by the Section of the History of Library in Beijing Daixue Xuebao (Journal of Beijing University) 18 (October 1959): 96.

Wong, W.S. "The Development of Archives and Libraries in China: an Historical Account." Libri 26(2) (June 1976): 140-155.

Wu, Jianxin. "Moving into the Big time." Beijing_Review no. 2 (May 1993): 55-57.

Wu, Wei-ci and Zhang, Shu-hua. "A Record of Chinese Librarianship in the Past Thirty Years." Tushuguan Gongzue (Library Work) no. 2 (May 1978): 4-9.

Wu, Zhi. "China: History , Politics/Foreign Affairs." Far Eastern Economic Review v.57:10 (March 1991):16-17.

Wuhan University, "Wuhan Daxue Tushuxinxi Xi." (The College of LIS Established in Wuhan University) Wuhan: Wuhan University Press, 1984.

Xiao, Dongfa. "Forty Years of Library and Information Education in New China, 1949-1989." Tushuguanxue Tongxun (Librarianship Bulletin) 1 (1988): 3-10.

Xie, Chao-hua, ed. Zhonggue Tushu He Tushuguanshi. (History of Chinese Books and Libraries) Wuchang: Wuhan University, 1987.

Yang, Sun. "Library Education in 2000." in Research Materials in Chinese Librarianship, (in Chinese) 18-25 Beijing: China Society of Library Science, 1984.

Ying, Quan. "How to Evaluate the Development of Chinese Library Service." Tushuguan Gongzuo (Library Work) no. 8/9 (1957): 4-7.

Yuan, Ding. "Shift the Focus of Library Service to Socialist Modernization." (in Chinese) Tushuguanxue Tongxun (The Bulletin of Library Science) no. 1 (June 1979): 2-12. 
Zanielly, T.A. "Flowers in Full Bloom: the Variety of Chinese Children's Literature." Children's Literature 7 (1977): 181-190.

Zhu, T. "Thirty Years of Correspondence Education in Library Science in China." Education and Research in Library and Information Science in the Information Age 6 (1988): 167-172. 